\title{
THE STANDARD OF LiVIng IN LATIN AMERICA OVER THE TWENTIETH CENTURY
}

\author{
Pablo Astorga, Ame R. Bergés and Valpy FitzGerald \\ Latin American Centre, St Antony's College, Oxford OX2 6JF
}

New and consistent series for Latin American real incomes, life expectancy and adult literacy over the twentieth century reveal that living standards rose most rapidly between the nineteen-thirties and -seventies, a period characterised by increased state intervention and reduced trade openness. Within the region, Brazil and Mexico advanced most over the century as a whole despite the early start made by Argentina and Chile, although convergence between larger countries was accompanied by divergence from smaller ones. There was no sustained narrowing of the income gap with the US at all between 1900 and 2000 but some convergence in living standards due to improved life expectancy. Our new estimates of regional per capita income also permit a clearer comparison with both Europe and Asia. The major advances in living standards achieved in the middle decades of the century were closely related to early industrialisation, rapid urbanisation and the extension of primary health and education. Subsequent economic volatility and fiscal fragility limited further increases in living standards, undermining social consensus on development strategy.

Keywords: Economic History, Economic Development, Living Standards, Welfare, Education, Income and Wealth, Latin America \& Caribbean

EconLit Subject Descriptors: E100, I310, N160, N360, O100. 


\section{Introduction ${ }^{1}$}

Although the leading Latin American economies started the twentieth century with living standards comparable to those of Southern Europe, and per capita incomes grew five-fold over the century, by 2000 the region still ranked as 'middle-income developing' by World Bank criteria and enjoyed relatively low 'human development' levels according to the UNDP. Despite a large and distinguished literature on Latin American economic history, there is little consensus as to why its development experience has been so disappointing, particularly in recent decades. Moreover, rigorous quantitative research has been hampered by a lack of reliable and comparable estimates of living standards for the region over the long run.

The recent literature on long run economic trends in Latin America (e.g. Hofman, 2000 or Bulmer-Thomas, 1994) focuses on output and trade issues, and has not benefited from consistent and comparable national GDP series for the twenty economies in the region, let alone other social indicators that might reflect standards of living more widely than GDP per capita. We have recently compiled new series from primary sources on a comparable basis for per capita income, life expectancy, and literacy which permit more reliable estimation of living standards in six major economies (Argentina, Brazil, Chile, Colombia, Mexico and Venezuela, or the 'LA6') since 1900 and in the remaining 13 countries ('LA13': Bolivia, Costa Rica, Dominican Republic, Ecuador, El Salvador, Guatemala, Haiti, Honduras, Nicaragua, Panama, Paraguay, Peru, and Uruguay) since $1950 .^{2}$

\footnotetext{
${ }^{1}$ Pablo Astorga is at Oxford Economic Forecasting; Ame Bergés is at the Latin American Centre, University of Oxford; and Valpy FitzGerald is Reader in International Economics and Finance, University of Oxford. We are grateful to the Hewlett Foundation for research funding. We also thank the anonymous EHR referees, and participants at the LSE Comparative Economic History Seminar, the Latin American and Caribbean Economics Association and the Nuffield Economic History Seminar for useful comments on earlier versions.

${ }^{2}$ This paper focuses mainly on the countries that comprise the LA6 because they account for about three quarters of population and output and thus can be taken to represent the region as a whole. Cuba is excluded from the LA13 due to lack of comparability but its main indicators are shown in the Appendix. The database is available online free of charge at http://oxlad.qeh.ox.ac.uk/. For further details, see the Appendix to this paper.
} 
As Table 1 below shows, between 1900 and 2000 real per capita incomes in the LA6 grew at a compound rate of growth of 1.8 per cent per annum. ${ }^{3}$ Literacy rates and life expectancy more than doubled. Similar improvements are also evident in the smaller less industrialised Latin American countries, although to a lesser degree. Incomes in the 'LA13' grew at only 1.0 per cent per annum between 1950 and 2000, and with average literacy rates lagging behind the LA6 by about two decades and life expectancy by about a decade - although there were notable exceptions of small countries where both these indicators exceeded those of larger ones and approached US and European levels.

<Table 1 about here>

The paper attempts to measure and to some extent explain these changes in Latin American living standards over the twentieth century. In Section 2, growth rates and volatility of per capita income are examined and support a classification of Latin America's long run development into three main periods: 1900-39, 1940-80 and 1981-2000. This growth periodisation is a familiar one to historians of the region but we find that the differences are even more marked in terms of volatility. Section 3 presents new estimates of per capita income data with life expectancy and literacy as wider indicators of living standards. A composite living standards index based on the UN Human Development Index suggests that Latin America experienced the greatest progress in social as well as economic terms during the middle decades of the century. Section 4 shows that despite considerable productivity (and thus income) convergence within the region, Latin American incomes not only failed to converge on US levels throughout the century, but also lost ground initially gained relative to Europe and Asia. None the less, the 'social gap' is shown to have narrowed in terms of literacy and life expectancy as the result of urbanisation and public interventions in health and education. Section 5 concludes with a discussion of possible interpretations of these long run trends in Latin American living standards.

\footnotetext{
${ }^{3}$ The LA6 and LA13 sub-regional averages are population-weighted means of country values.
} 


\section{Long run income trends in Latin America}

An assessment of living standards in Latin America over the twentieth century depends on reliable estimates of per capita income. Gross domestic product (GDP) at constant prices, in national currencies or at the current dollar exchange rate, must be adjusted for purchasing power parity (PPP) in order to be comparable between countries. ${ }^{4}$ Ideally, these PPP conversion rates would be estimated at (say) decade intervals to reflect the changing production structure and openness of the economy. However, in the absence of comprehensive price data for the whole century there is no feasible way of producing dynamic PPP adjustors; and indeed the major international studies do not even provide country-specific adjustors for Latin America in recent decades. ${ }^{5} \mathrm{We}$ have therefore used the most comprehensive available set of the PPP conversion factors based on primary price data for Latin America, which is that estimated by the ECLAC on the basis of dedicated country surveys in $1970 .^{6}$

These ECLAC adjustment factors were applied to the GDP series in constant local currency units rebased to 1970, which raises the ratio of PPP-adjusted GDP per capita to GDP per capita in nominal dollars for individual countries by between 20 and 40 percent in that year. However, as countries industrialise, integrate more closely into world markets and experience greater factor price equalisation, we would expect a downward trend in this PPP adjustment. To further complicate matters, 1970 was a relatively 'trade protected' year relative to the opening and closing decades of the century, when the 'true' adjustment factors may well have been lower. This potential measurement bias means that our income levels are probably somewhat overestimated for the opening and closing decades of the century. ${ }^{7}$ None the less, our estimates appear to be consistent with the leading source for modern PPP estimates: taking the ratio of Argentine to US per capita PPP-GDP in 1990 as a benchmark, our estimate

\footnotetext{
${ }^{4}$ This is because of the impact of trade and exchange rate controls on relative traded prices, and of local wage levels on non-traded prices.

${ }^{5}$ The two most widely used sources of long-term PPP-GDP per capita, Heston and Summers (1991) and Maddison (2001), do not report PPP adjustment rates for all Latin American countries and in many cases (especially in Maddison) appear to have been imputed rather than directly estimated from primary sources.

${ }^{6}$ See ECLAC (1978), p. 8; and Table A3 below for further details.

${ }^{7}$ However, even if it were possible to correct for this bias, the correction would only further strengthen the finding of this paper that growth was higher in the middle period. See Figure 10 for the changes in trade openness over the century.
} 
(see Table A1) of this ratio is 15 percent, compared to 13 percent by in Heston \& Summers, which is well within the margin of error. ${ }^{8}$

Figure 1 shows per capita income trends for Latin America over the century. The fitted trends confirm that there is a clear 'periodisation' of the century, with higher growth rates in the middle decades than at the beginning or the end. ${ }^{9}$ The two main points of inflexion (given by a change in sign of the second derivative of the fitted trend) in the LA6 series occur in 1939 and 1980: this periodisation coincides with that used by authors such Hofman (2000) and Bulmer-Thomas (1994) derived from shifts in policy regime; and with that suggested by Fajnzylber and Lederman (1999) on the basis of trade openness and total factor productivity growth. Admittedly, the choice of 1900 and 2000 to frame our period is imposed by data limitations. However, data for opening years of the twenty-first century show a continuation of per capita income growth and volatility patterns similar to those of the last two decades of the twentieth century. ${ }^{10}$ Historians of Latin America would doubtless prefer us to have extended the series back towards 1880 , when the export-led 'liberal' period began, ${ }^{11}$ but sufficient data is not yet available on a comparable basis to do this.

$<$ Figure 1 about here>

Table 2 shows growth rates and instability (expressed as the standard deviation of the growth rate during the period and 'volatility' - the coefficient of variation) in LA6 GDP per capita in 1970 PPP dollars during the three main periods: 1900-39, 1940-80 and 1981-2000. The first period is characterised by relatively moderate growth rate

\footnotetext{
${ }^{8}$ However, Maddison gives a somewhat implausible value of 30 percent for this ratio; and indeed most of his estimates of Latin American long run real income levels appear to be too high.

${ }^{9}$ The fitted trend for the LA6 $1900-2000$ is $y=-6 \mathrm{E}-05 \mathrm{x}^{4}+0.4788 \mathrm{x}^{3}-1397.2 \mathrm{x}^{2}+2 \mathrm{E}+06 \mathrm{x}-$ $9 \mathrm{E}+08\left(\mathrm{R}^{2}=0.990\right)$. That for the LA13 $1945-2000$ is $\mathrm{y}=-0.0016 \mathrm{x}^{3}+9.6152 \mathrm{x}^{2}-18768 \mathrm{x}+$ $1 E+07\left(R^{2}=0.909\right)$. Naturally, the precise dating of these periods differs by individual country by a few years, but preliminary econometric estimates of structural breaks in a VAR model for each of the LA6 separately reveals a remarkably similar pattern with the breaks for individual countries only differing by a few years from those reported here - see (Astorga, Bergés, and FitzGerald (2005).

${ }^{10}$ ECLAC (2003) reports negative per capita GDP growth during 2001-3 (- 1.0\%) for the regions as a whole, and $-3.0 \%$ for the LA6, due to the collapse of both Argentina and Venezuela.

${ }^{11}$ See Cárdenas, Ocampo and Thorp (2000a).
} 
and volatility; the second period by a much higher rate of growth for all the LA6 (except Venezuela) and lower volatility; and the third period by lower and more volatile growth than in either of the previous periods. Figure 10 shows how trade openness broadly coincides with this periodisation. The LA13 pattern is broadly similar, with high growth and low volatility in the $1945-80$ period followed by negative growth and high volatility in 1981-2000. Moreover, Latin America is recognized as having the worst income distribution of any region in the world, and that this deteriorated during the last three decades of the century (Thorp, 1998; Stallings and Peres, 1999).

These trends reflect the dominance of particular growth strategies: reliance on primary commodity exports as the main engine of growth in the first four decades; trade protection and state-led industrialisation in the middle four decades (including debt accumulation); and the recovery from debt crisis followed by of trade and financial liberalisation in the closing decades of the century. This characterisation is familiar from the literature, and we shall return to its interpretation in Section 5 However, these results also reveal a feature of the growth process that does not appear to have been discussed in the literature: volatility as defined by the coefficient of variation in the annual growth rate varied between the three periods quite as much as the average growth rate itself. Indeed as well as being an obvious disincentive to capital accumulation and potential source of social conflict, this volatility can be regarded as a substantial collective welfare loss by conventional criteria of risk valuation. ${ }^{12}$ Moreover, with the exception of Costa Rica, the performance of LA13 is substantially worse than that for the LA6. This may be due to the inability of smaller domestic markets to act as a buffer for exogenous shocks.

$<$ Table 2 about here>

Table A1 in the Appendix also provides evidence that per capita income in the LA6

\footnotetext{
${ }^{12}$ Volatility is usually valued as a discount reflecting the premium $\left(\pi=\frac{1}{2} \phi \sigma^{2}\right)$ that an investor would be willing to pay for a riskless portfolio with the same expected returns. Applying the a conventional value for the constant relative risk aversion $(\phi)$ of 0.5 would imply a 'collective risk premium' for the LA6 during our three periods of 3.1 per cent of GDP per capita for 1900-39, 1.0 per cent for 1940-80 and 1.4 per cent for 1981-2000.
} 
countries has converged over the century, although the absolute differences in income remain substantial. Argentina opened the century as the richest country by far with twice the per capita income of Chile, Colombia and Mexico, and nearly five times that of Brazil and Venezuela. By the end of the century, however, Mexico and Chile had incomes equal to that of Argentina; while Brazil, Colombia and Venezuela had narrowed the gap by two-thirds. A similar process is also evident from the declining dispersion of income levels within the LA13 group between 1945 and 2000. This intra-group convergence contrasts with the inter-group divergence of mean income levels between the LA6 and LA13 after 1945 at least, with the ratio between average incomes in the two groups rising from 1.4 in 1950 to 2.0 by 2000. This suggests that there may be at least two 'growth clubs' in the region that exhibit conditional convergence. ${ }^{13}$

\section{Trends in social conditions and living standards}

While growth in output in Latin America over the twentieth century has been extensively discussed in the quantitative economic history literature (although not with such consistent data as in the previous section), discussion of social indicators of living standards has been based on fragmentary and non-comparable series. ${ }^{14}$ Figures 2 and 3 show that both literacy and life expectancy exhibit the familiar 'logistic' pattern in Latin America over the twentieth century, with the greatest improvement between 1940 and 1980. Literacy rates - a key component of human capital in the early industrialisation process - in the LA6 rose from 33 percent of the adult population in 1900 (probably similar to Southern Europe at the time) to 53 percent in 1940, 81 percent in 1980 and 89 percent in 2000. The LA13 followed a similar pattern but with a considerable delay, rising from 25 per cent literacy in 1900 to 40 percent in 1940 and 82 per cent by 2000 - in other words, a lag of some two decades on average.

<Figure 2 about here>

\footnotetext{
${ }^{13}$ As in Baumol (1986) - our econometric analysis of these series is set out in Astorga, Bergés, and FitzGerald (2005).

${ }^{14}$ See Thorp (1988), which contains our first estimates of long run literacy and life expectancy for Latin America.
} 
Life expectancy - perhaps the most fundamental indicator of welfare - increased by an average of three years per decade from 1900 to 1940 in the LA6, rising from 29 to 40 years. Between 1940 and 1960, life expectancy improved by a further 17 years to 57 , and reached a quite creditable 70 by 2000 . The LA13 again lagged behind the LA6, with life expectancy rising from 46 years in 1950 to 67 by 2000 (Figure 3). The fact that the LA6 and LA13 experienced the most rapid improvements in life expectancy in successive decades suggests a common pattern of intervention or of social change. The subsequent slowdown in literacy and life expectancy improvements partly reflects their natural asymptotes.

$<$ Figure 3 about here>

These advances in education and health clearly improved the quality of the labour force and contributed to productivity growth. The accumulation of physical and human capital stock accounts for nearly all the productivity growth experienced in twentieth century Latin America (as opposed to total factor productivity growth resulting from technological or institutional transformations) and investment rates in both these stocks were most rapid during the middle decades of the century. ${ }^{15}$ There were two main causes for the higher rate of improvement in both literacy and life expectancy during the middle decades of the century: on the one hand, expanded state social intervention with targeted public expenditure on health and education; and on the other, the process of urbanisation itself with a majority of the population shifting to towns with better social infrastructure than the countryside.

In the case of literacy, the improvement evident in the middle decades to a great extent reflects not only urbanisation but also large-scale campañas de alfabetisación, organised for political (or at least 'citizenship') motives as much as for welfare reasons, and the lagged returns on public investment in primary education in the first third of the century. ${ }^{16}$ The logistic shape of the curve for literacy over time was

\footnotetext{
${ }^{15}$ See Astorga, Bergés, and FitzGerald (2003).

${ }^{16}$ For the Mexican urban working classes, secular education was a priority and remained a main focus of the Revolution, see Knight (1984). The Socialist party in Argentina also made
} 
already typical of the Industrial Revolution (Meyer et al., 1992), but seems in the Latin American case to have been more rapid than in US or Europe in the sense that the mid-century slope was steeper. This slope is comparable, however, with other developing regions in the last quarter-century of 'global literacy transition' (Wils, 2002), albeit much earlier and without the benefit of foreign assistance.

Increasing life expectancy was probably due to declining infant mortality rather than increased adult longevity during the first half of the century, as in 1900 the mortality distribution was presumably dominated by infant deaths as in other cases of early industrialisation. ${ }^{17}$ By 1960, when we do have comparable data (see Table 3) adult mortality dominates, but even so the reduction in infant mortality in the following decades is far more rapid than that for adults. By 2000, in fact, the overall mortality pattern is strikingly similar to that for the US in 1960 even though 2000 incomes in Latin America were only a quarter of those in the US in 1960. As with literacy, we cannot simply attribute this social progress simply to economic growth: targeted public spending (particularly on urban sanitation) helped eradicate infectious diseases and lower infant mortality. ${ }^{18}$ It is likely moreover, that the improvements in literacy had a positive effect on life expectancy by improving both maternal skills and the ability to access public services. ${ }^{19}$

\section{<Table 3 about here>}

The relationship between urbanisation and living standards during early industrialisation is not necessarily positive. Urbanisation led to lower life expectancy in Europe and Great Britain until at least the mid-nineteenth century, showing an improvement only from the 1870 s onwards. ${ }^{20}$ The experience in Latin America appears to be different, due perhaps to later urbanisation when public sanitation was more widespread and disease better understood. In 1900 Uruguay had the highest

education central to their platform, with heavy emphasis on literacy and public, secular education, see Adelman (1992).

${ }^{17}$ See Offer (2000).

${ }^{18}$ In Brazil, for instance, as early as 1902-6 Rodrigues Alves administration prioritised the eradication of yellow fever and smallpox, implementing programs of public works, urban renewal, and public health and disease control (Meade, 1989).

${ }^{19}$ As suggested by Riley (2001).

${ }^{20}$ Szreter and Mooney (1998), see also Riley (2001). 
level of urbanisation in Latin America and the highest life expectancy (see Table A7): at 49 years it was the same as the US at that time even though its income level was only one third. Argentina was in a similar situation. ${ }^{21}$

Table 4 summarises the proportion of population considered to be urbanised from 1900 to 2000 in Latin America: the major change is clearly in the middle decades of the century, when the population shifts from being mainly rural to mainly urban. The earlier developers in the region (such as Argentina and Chile) make this transition rather earlier than the later ones such as Mexico and Brazil (see Table A7). The difference between the rates of urban and rural literacy in Table 4 imply that the process of migration led to higher educational standards in the middle decades, mainly from better access to primary schools. Only later did rural literacy levels begin to catch up, often supported by mass literacy campaigns. Data limitations prevent a comparison of urban and rural life expectancy over the century but it is highly probable that economies of urbanisation had a positive effect on public investment in potable water and sanitation, the application of public health measures, and on broader access and distribution of medical treatment (including cheaper antibiotics) in urban areas.

$<$ Table 4 about here>

Composite indices of living standards that combine economic and social indicators facilitate the international comparison of living standards, but require a number of strong assumptions. The best known of these composite indices is the 'Human Development Index’ (HDI) developed by the United Nations, which incorporates three indicators: per capita income (in logarithmic form to reflect declining marginal utility of income); a weighted average of educational enrolment and literacy; and life expectancy. ${ }^{22}$ The use of the marginal utility notion to scale per capita income and the equal weighting for the three components of the index itself are clearly both arbitrary, although arguably no more so than not scaling per capita income at all. ${ }^{23}$ Despite

\footnotetext{
${ }^{21}$ See Laks (1971).

${ }^{22}$ See UNDP (2002).

${ }^{23}$ This weighting is defended by the UNDP op. cit. on the grounds that there is no way of ascertaining the substitutability of any one variable for any other variable. Evidence on the market valuation of longevity (e.g., from insurance data) or education (e.g., returns to
} 
these limitations, this approach is increasingly used in the economic history literature in order to make meaningful comparisons between living standards in countries over the long run that do not rely on GDP per capita alone (Crafts, 1997).

We have for this purpose constructed a 'Historical Living Standard Index' (HLSI) that is similar to the HDI in structure with two important differences: first, due to limited data availability and coverage on enrolment rates, literacy is the only indicator of education; second, for purposes of long run comparison, the indicators are measured against a single 'benchmark' rather than relative to other countries in that year. The HLSI for country $i$ in any one year $t$ is thus defined as:

$$
H_{i t}=\frac{1}{3}\left[\left(\frac{\log Y_{i t}-\log 100}{\log 40,000-\log 100}\right)+\left(\frac{L_{i t}-25}{85-25}\right)+\left(\frac{E_{i t}-0}{100-0}\right)\right]
$$

where $Y$ is per capita income in 1970 international dollars, $L$ is life expectancy at birth in years and $E$ is the literacy rate. The HLSI thus compares the actual situation of country $i$ in year $t$ to that of an ideal hypothetical country with GDP per capita of US $\$ 40,000$, life expectancy of 85 years, and literacy rate of 100 per cent - for which the index value would be unity. ${ }^{24}$

Figure 4 illustrates the overall movement of our HLSI from 1900 to 2000. This shows that the standard of living in the LA6 - and thus for the majority of the Latin American population - almost doubled between 1900 and 1939 and more than doubled to 1980 , but had risen again only marginally by the end of the century. The increase in living standards for the LA13 stagnated after 1980 as well. As we argue in Section 5 below, this pattern goes some way to explaining the degree of popular support for the industrialisation strategy in the middle period and the corresponding lack of support for the subsequent economic liberalisation.

$<$ Figure 4 about here>

schooling) might be used (see for instance Usher 1980), but such evidence is not available over time or on a comparable basis for Latin America.

${ }^{24}$ This benchmark is, of course, that used for the HDI (UNDP 2002). 
Our Historical Living Standard Index also allows us to shed some light on the convergence process within the region. As illustrated in Figure 5, there is strong evidence of a catch-up process within the LA6. The richest countries with the highest initial standard of living in 1900 were Argentina and Chile, with index values twice those of Brazil and Mexico and institutional development to match. However, the gap had been almost completely closed by 2000 . The period between 1935 and 1980 was critical for the catch-up process; after 1980, living standards in the two sets of countries decelerated together. Interestingly, the countries with the best social indicators at the outset (Argentina and Chile) grew less rapidly in economic terms over the century, while those with the worst (Mexico and Brazil) grew most rapidly. On the one hand, low initial stocks of human capital clearly did not prevent Brazil and Mexico from growing more rapidly and steadily than Argentina and Chile; nor were the accumulated stocks after 1980 sufficient to sustain growth. On the other hand, the expansion of health and education during the middle decades of the century was due more to public service provision and urbanisation than to income growth as such; and social indicators continued to rise after 1980 even though per capita incomes stagnated. Both these findings imply that the relationship between economic and social progress - in either causal direction - may not be so close as often supposed, at least in the case of Latin America. We return to this discussion in Section 5.

$<$ Figure 5 about here>

The only comparable exercise to this in the economic history literature is Crafts (1997), who argues that GDP per capita is inadequate as a measure of long run living standards because imputations for additional elements may be quite sizeable. His application of the HDI to developing countries in recent decades in comparison to industrial countries in the late 19th century industrial countries reveals surprisingly high living standards in the former due to the large increase in life expectancy. As the next section shows, life expectancy is also the main source of Latin American convergence on the USA during the twentieth century. Crafts (2002) uses the revised income version of HDI as we do, and finds that this further reduces the gaps between the leading economies and both Africa and India in 1913 and in 1950; that the HDI value for most of today's less-developed countries exceeds that of Western Europe in 1870; that the differences in HDI between Western Europe and each of Africa, China 
and India were smaller in 1999 than in 1950 due to widespread gains in life expectancy; and that increases in HDI are generally greatest in countries that were in some way behind the leaders in 1950. Broadly speaking, our results confirm those of Crafts in terms of convergence: with the US this is mainly due to life expectancy; and within the region the late starters perform best.

But this is not a rosy picture: in terms of absolute levels (see Tables 5 and A5) we find that despite the convergence in literacy and life expectancy, the large income gap even between Latin America in 2000 and the USA (and Northern Europe) in 1900 means that the standard of living in the LA6 in 2000 is now only equivalent to that of the US in 1930 and that for the LA13 hardly exceeds the US level in $1900 .^{25}$

$<$ Table 5 about here>

\section{Comparative living standards in Latin America and the rest of the world over the twentieth century}

Throughout the century, Latin Americans regarded the United States as the logical basis for judging their own relative living standards. Further afield, Southern Europe had been the traditional basis for comparison, but in the last quarter of the century Asia became the benchmark as European social standards seemed unattainable and Asia began to catch up economically. Table 6 shows the ratio of Latin American per capita income, literacy, and life expectancy to US levels. Broadly speaking, life expectancy and literacy converged on US levels by the end of the century, but incomes failed to follow suit.

$<$ Table 6 about here>

The ratio of per capita incomes in Latin America and the US is illustrated in Figure 5

\footnotetext{
${ }^{25}$ The pre-1950 group means for LA13 are not very reliable, due to the fragmentary nature of the data for these countries, which is why they are not shown in Figures 1-8.
} 
in greater detail. The asymmetric economic cycles in the northern and southern Americas account for the considerable fluctuations in this ratio over time, but although a divergent trend is clear for the LA13, there appears to be no long-term trend for the LA6. ${ }^{26}$ The greatest narrowing of the income gap for the LA6 occurred in the 1930s, which is explained by the fact that Latin American output fell by much less than that of the US during the Great Depression, and recovered more rapidly largely due to effective protection provided by exchange shortages and trade policy. ${ }^{27}$ However, this gain was short-lived and lost again during the WWII boom in the US. Although as Figure $6 \mathrm{~b}$ indicates, LA6 growth was similar to and steadier than in the US until the early 1980s, a marked divergence is evident thereafter - the result of the product of the long US boom on the one hand and a series of Latin American macroeconomic crises combined with the failure to develop a dynamic manufactured export base in all countries except Mexico. After some gains relative to US income levels in the late 1940s, the LA13 steadily declined relative to the US, especially after the 1980s for much the same reasons as the LA6.

$<$ Figure $6 \mathrm{a}$ and Figure $6 \mathrm{~b}$ about here $>$

The convergence in literacy rates shown in Tables 4 and A4 is notable but quite steady and not entirely unexpected because of the existence of a natural limit: international comparisons of the extent and quality of education with other developing regions shows a less positive picture. ${ }^{28}$ Convergence of LA6 life expectancy at birth with US standards, in contrast, is remarkable (Figure 7) - particularly since it mainly occurred during the four decades 1940-80 and as we have seen, reflected increased adult life expectancy as much as declining infant mortality. The LA13 followed closely behind. In this respect, Latin American nations could be considered to have

\footnotetext{
${ }^{26}$ Standard cointegration tests indicate that over the century as a whole the ratio of LA6 per capita income to the US is in fact stationary, see Astorga, Bergés, and FitzGerald (2005).

${ }^{27}$ The internal demand stimulus created by effective protection was strengthened by fiscal expansion and infrastructure provision: see Cárdenas, Ocampo \& Thorp (2000b). This in turn led to rising rates of domestic investment (Astorga, Bergés, and FitzGerald, 2004)

${ }^{28}$ Although the region had reached 95 percent primary and 65 percent secondary enrolment rates by 2000 (World Bank, 2004), Chile - the only Latin American country to participate in the 1999 Third International Mathematics and Science Study - came $35^{\text {th }}$ out of 38 entrants, well behind Malaysia and Thailand, see PREAL (2001), p. 6.
} 
been rather more effective in extending their citizens' lives than in raising their incomes. $^{29}$

$<$ Figure 7 about here>

The convergence of life expectancy, particularly when combined with the assumption of a declining marginal utility of income in our HLSI measure, suggests that there has indeed been limited convergence of living standards in the LA6 and the LA13 relative to the USA (Figure 8), despite the large gap in relative income. ${ }^{30}$ Moreover, despite growing divergence in per capita incomes, some of the smaller countries in the LA13 were also able to make impressive gains on living standards relative to the US. Uruguay, Costa Rica, and Cuba are three notable examples. Even as early as 1900, life expectancy at birth in Uruguay was slightly higher than that of the US (Table 6) and still only slightly below in 2000. Costa Rica and Cuba were both able to approximate US life expectancy and literacy standards by the end of the century too. Insofar as standards of medical care and schooling are logically higher in the US for the upper economic quintile(s) than in Latin America, this might be taken to imply that in these three countries at least, primary health and education provision for the lower strata of the population may even be better than in the US.

$<$ Figure 8 about here>

As we have seen, the LA6 maintained a fairly steady ratio of incomes to the US level over the century and as Figure 9 below shows, there been no sustained economic convergence with the Northern European countries (England, France, and Germany), but Latin America has also fallen behind the Southern Europe and Asia in the second half of the century. Between 1900 and 1930, average LA6 incomes ranged from a quarter to a third of those in Southern Europe. With the depression and war in Europe, as well as Latin America's stronger growth performance, the gap narrowed

\footnotetext{
${ }^{29}$ Increased longevity should presumably be adjusted for health quality in old age: however, despite the evident superiority of US geriatric medicine, family support in Latin America may well provide a comparable quality of care in old age.

${ }^{30}$ The gap also extends to the proportion of GDP spent on public health and education, which were both about double in the US compared to the LA6 in the 1990s. Expressed in PPP-dollars, the absolute level of per capita expenditures on public health and education in the LA6 each about 5 percent respectively of the US levels - data from UNDP (2002).
} 
considerably such that by 1945 it had reached about half of Southern European levels. By 1960, however, the original gap had been restored: high returns on human capital investment coupled with the process of economic integration prompted an acceleration of Southern Europe's growth rate, while the emergence of the welfare state raised longevity. Subsequently the gap steadily widened.

$<$ Figure 9 about here>

The Argentine case offers a telling illustration. In 1900, Argentina was relatively well-positioned vis-à-vis the Southern European countries, with a comparable per capita income of $\$ 487$ versus $\$ 632$ (at 1970 PPP prices). In consequence, it could attract major immigration flow of skilled labour from Spain and Italy seeking opportunities for upward social mobility. Despite the fall in world demand for its main exports and exclusion from British Dominion trade in the twenties and thirties, Argentine income levels during the forties climbed to an average of 86 per cent of those in Southern Europe. Subsequently, political and economic instability and persistent distributional conflict saw a steady decline in Argentine income levels to just 24 per cent of those in Southern Europe by $2000 .^{31}$

Perhaps surprisingly, LA6 per capita PPP-GDP was only slightly above Asian (India, Indonesia, and Korea in our index ${ }^{32}$ ) between 1900 and 1939; but this advantage rose sharply in the 1940s due to sustained growth in Latin America and the effect of the World War on in Asia. This advantage was maintained and increased up to 1980, when Latin American incomes were double those in Asia. Only subsequently did the combination of the Asian 'miracle' and low growth in Latin America dramatically eliminate this advantage, so that by the end of the century the two regions again had similar income levels. The roots of this experience lie in part in the differential impact of global conflicts, but also to the different way in which the two regions moved on from the shared initial experience of 'extensive' industrialisation based on import protection and state intervention.

\footnotetext{
${ }^{31}$ According to Portantiero (1989) this cannot simply be attributed to 'policy failure' or even to the lack of appropriate economic institutions, but rather to the prolonged stalemate between conflicting social groups which in turn prevented political modernisation.

${ }^{32}$ These countries are chosen because their data coverage permits analysis for the whole period from 1900 to 2000: see Appendix for sources.
} 


\section{Interpreting the Latin American Standard of Living in the Long Run}

This paper has made use of a new long run inter-country comparable data set for Latin America to examine the evolution of living standards in the region from 1900 to 2000. Our main findings are as follows:

a) Not only were Latin American per capita income growth rates between the nineteen-forties and nineteen-seventies both significantly higher and less volatile than in the preceding and succeeding decades, but social progress (measured by literacy and life expectancy) was also more rapid;

b) Improvements in Latin American living standards, both in absolute terms and in relation to industrialised countries, were due as much to improvements in life expectancy and literacy - two 'transitions' resulting from rapid urbanisation and increased public expenditure - as to economic growth;

c) There was considerable economic and social convergence between the largest six economies of the region over the century, reflecting similar patterns of industrialisation, urbanisation and public provision; but the smaller countries did not participate in this convergence process;

d) There was no economic convergence with the USA over the century as a whole; and by 2000 living standards in the larger economies only approximated those of the US in the 1930s; while those in the smaller ones did not exceed the US level in 1900;

e) Not only did the income gap with Southern Europe (which had been closing in the first half of the century) widen in the second half, but the leading Asian economies also caught up once again with Latin America;

f) Progress in health and education appears to have been largely independent of economic growth as such, depending rather on public intervention and urbanisation and thus on fiscal and industrial structures.

Some of these results confirm those already familiar from the economic history literature, but this is the first time that comparable data over time and space has been used to demonstrate them systematically. The quantitative difference between the 
economic and social results for 1939-1980 and the rest of the century is larger than in previous studies, and underlines the need for a renewed debate among economic historians on the strengths and weaknesses of the process of state-led industrialisation now that the initial over-enthusiasm for the structural reforms of recent decades themselves largely a reaction to the previous development strategy - has largely abated (Cárdenas, Ocampo, and Thorp, 2000b). ${ }^{33}$

It is now clear that the four decades in the middle of the century stand out for the outstanding progress made by nearly every country in the region. This was the period of increasing manufacturing share in output and rising labour productivity in both industry and agriculture ${ }^{34}$, as well as a shift in labour force allocation from primary to secondary sectors that accompanied the urbanisation process. ${ }^{35}$ It is difficult to avoid the conclusion that greater reliance on the domestic market was a major source of growth during the so-called 'import substitution' phase of state-led industrialisation. Urbanisation, associated with industrial employment, and public expenditure on health and education were key drivers of improved standards of living as we have shown in this paper. This period also saw the greatest structural change in the Latin American economy, and was marked by sustained and relatively stable growth and social improvement. Our preliminary estimates show that the region experienced higher total factor productivity growth and higher investment in fixed capital per worker in these mid-century decades (Astorga, Bergés and FitzGerald, 2004). ${ }^{36}$ In contrast, the periods from 1900 to 1940 and from 1980 to 2000 saw lower economic growth and far more instability; derived from less investment and productivity change.

It cannot said that 'institutions' were in some sense 'better' in general during the

\footnotetext{
${ }^{33}$ The recovery of most Latin American economies in the early 1990s was adduced as evidence by many 'orthodox' authors (such as Edwards (1995) or Easterly, Loayza, and Montiel (1997)) that the liberalisation process was bearing fruit; but subsequent events did not justify this optimism. Meanwhile, more 'heterodox' observers showed that while the economic gains were modest at best, the concurrent increase in inequality across region had led to rising poverty levels (Stallings and Peres (2000), Taylor (1999), and Ffrench-Davis (2000).

${ }^{34}$ Due to the reduction of surplus labour in agriculture as well as technological change.

${ }^{35}$ The data on this process is analysed in depth in Astorga, Bergés and FitzGerald (2004).

${ }^{36}$ Indeed, our estimates (op. cit) indicate that the level of fixed capital per worker hardly rose at all between 1980 and 2000, while the productivity of manufacturing labour actually declined.
} 
middle of the century than before or after; nor that the highest performing countries (Brazil and Mexico) had better institutions - particularly at the outset - than those that performed less well such as Argentina and Chile. However, Figure 10 does imply that poor economic growth and greater volatility in the first and third periods could be related to the degree of exposure to world markets, as measured by the trade-to-GDP ratio. The main channel for transmitting volatility is commodity prices ${ }^{37}$, while trade openness may also proxy for exposure to international financial markets - which tend to have a pro-cyclical effect. By extension, the considerable growth differences between larger and smaller countries in Latin America may well be due to smaller export to GDP and debt to GDP ratios in the former which heighten the vulnerability of smaller countries to trade and interest rate shocks. (Astorga, Bergés and Fitzgerald, 2005).

$<$ Figure 10 about here>

This view is open to two criticisms. The first is that most of the world economy experienced rapid rates of growth in the post-WWII decades, and the US itself during the War years, so that the Latin American experience was not unique or necessarily attributable to its industrialisation strategy. However, the upturn in the Latin American economy preceded that of the US in the 1930s while Southern Europe only accelerated in the 1970s when Latin America was decelerating. Moreover, when compared to Asia it is in the post-1980 period when Latin America falls seriously behind in the industrialisation race - opening its markets to manufactured imports rather than promoting manufactured exports. In other words, the economic growth cycle in Latin America cannot simply be attributed to global trends.

The second criticism is that while the middle period did see reasonable growth and social progress, it was achieved at the cost of debt accumulation, which then explains

\footnotetext{
${ }^{37}$ Astorga, Bergés and FitzGerald (2005) apply error-correction models to the LA6 over the century: capital and (literacy adjusted) labour explain the underlying trends, and exogenous (and endogenous) shocks explain deviations from those trends. External demand factors (both world trade and the coefficient of variation in the terms of trade) appear to be particularly significant in the first and third periods, and domestic factors - particularly capital stocks - in the second.
} 
low growth during the subsequent liberalisation period. ${ }^{38}$ However, the debt crisis was fiscal in nature, and generated by an inability to raise tax revenue to modern levels rather than excess social expenditure or public investment, which implies that it was not caused by the industrialisation model as such. ${ }^{39}$ Indeed, the danger of creating inefficient industries behind tariff walls and unsustainable budget deficits were both well recognized by Latin American governments from at least the 1960s onwards and repeated efforts were made to both increase manufactured exports and raise tax revenues (FitzGerald, 2000). In 2000, after two decades of market reforms, fiscal retrenchment and trade liberalisation the Latin American debt burden had not been significantly reduced and tax pressure (particularly direct taxes) remained well below comparable OECD and developing countries. ${ }^{40}$ In contrast, in East Asia industrial protection did not lead to excessive indebtedness because of conservative fiscal policies; while when a debt crisis did occur after premature financial liberalisation in the 1990s, the trade deficit was quickly reversed and the debt paid off in a few years.

The issue can perhaps be better understood in terms of the changes in economic doctrine prevalent in Latin America. FitzGerald and Thorp (2005) show how frustration with the development experience before 1930 - based on open primary export economies - precipitated state intervention in domestic markets and protected industrialisation. Excess capacity inherited from previous industrial investment, trade protection provided by the collapse of world markets and unplanned fiscal deficits all supported this shift. After 1980 the experience of debt crisis and industrial inefficiency in their turn spurred a shift in focus towards trade liberalisation and foreign investment as engines of growth; at this stage, global investor interest in privatisations and pressure from Washington certainly helped push the reforms forward. However, the same study also stresses that these changes in economic ideology were driven by domestic and international political concerns in the deepest sense: the move away from economic liberalism towards public intervention and planned industrialisation responded to pressures from emerging urban classes and worldwide nationalist aspirations; while the move back to economic liberalism in the

\footnotetext{
${ }^{38}$ This was a dominant theme among economists associated with the so-called 'Washington Consensus': see for instance Dornbusch and Edwards (1991)

${ }^{39}$ See FitzGerald (1985) on Mexico and Kosacoff (2000) on Argentina.

${ }^{40}$ See Shome (1999).
} 
1980s formed an essential part of the transition to democracy throughout the continent, and also matched a similar trend worldwide.

These major strategy shifts were clearly associated changing living standards for the majority of the population during the twentieth century. The state-led industrialisation drive in the middle of the century was associated with rapidly rising living standards for a large part of the Latin American population, while the liberalisation strategy of the closing period has not had that effect - indeed living standards have risen less than in the equivalent primary-export led opening decades of the century. It is not difficult to understand therefore why there was widespread political support for the former model and continued political doubts about the latter. But there is little serious popular or intellectual support in the region today for return to the previous economic model, and it is not possible to repeat the early gains from import-substitution, urbanisation and public sanitation in any case. However, to significantly raise living standards in the region will require not only several decades of sustained economic growth but also radical fiscal reform in order to finance the acquisition of labour skills and inclusive social services if inequality is not to increase further. 


\section{Statistical Appendix}

International organisations such as the International Monetary Fund, the United Nations, the World Bank and the Economic Commission for Latin America and the Caribbean, provide comparative data for Latin America from approximately 1960 onwards. Data previous to 1960 can be found in compendia of historical statistics on the region such as Mitchell International Historical Statistics: The Americas, 1750-1993 or Wilkie Statistical Abstract of Latin America but these do not ensure compatibility of data for different countries nor complete coverage of the period. There are of course many excellent country studies, the most important of which are cited below, but as well as using different methodologies and definitions, most do not attempt complete coverage of the century. Bulmer-Thomas (1994), Maddison (1995), Hofman (2000), Mitchell (1998), and Wilkie (2002) all report longrun GDP series for the largest economies in the region (as well as other economic indicators) but these are not strictly comparable between countries and do not include social indicators.

The Oxford Latin American Economic History Database (OxLAD) originates from the work carried out for the statistical appendix to Thorp (1998); since considerably extended and systematised. Its purpose is to provide economic and social historians worldwide - and particularly in Latin America — with a systematic recompilation of available statistical information for the countries in the region for the period 1900 to 2000 in a single on-line source. The data presented have been selected with a view to providing comprehensive coverage while ensuring as much consistency and intercountry and over-time comparability as possible in the definition, coverage, and valuation of the series. Specifically, OxLAD provides extended comparable GDP and sectoral value-added series in constant purchasing power parity prices originally reported by ECLAC (1978) to 2000, and retroactively toward 1900s where possible.

Our GDP per capita estimates are summarised in Table A.1 below. The main difference between the GDP estimates in constant price valuation in international dollars reported in OxLAD and those in Hofman (2000) and Maddison (1995, 2001) lies in the estimates of purchasing power parities. Maddison (2001) relies on GearyKhamis purchasing power parities (PPPs) from phase IV of the International Comparisons Project (ICP IV), with 1980 benchmarks for Argentina, Brazil, Chile, Colombia, and Venezuela, and on Geary-Khamis PPPs from ICP III for 1975 
benchmarks for Mexico. ${ }^{41}$ The Hofman (2000) estimates were provided directly by Alan Heston (AH), with 1980 benchmarks for the LA6. OxLAD estimates rely on 1970 benchmarks for the LA6 from the Economic Commission for Latin America and the Caribbean (1978). These purchasing power parities (PPPs) are reported in Table A2. Comparison of PPPs and exchange rates shows that exchange rates are much higher than PPPs for all countries in the case of ECLAC (1970), and for all countries except Argentina in the case of the ICP IV and AH. The deviation between PPPs and exchange rates in Table A3 suggests that comparisons based on current exchange rates tend to understate GDP.

We have used the ECLAC series rather than the ICP IV and AH series mainly because the commodity bundle chosen for price comparisons is specific to Latin America, whereas that chosen in the ICP IV and AH is more general to encompass price comparisons and average international prices applicable to industrialised, semiindustrialised, and least developed countries alike from across the globe. Although the ICP programme is carried out separately for six different regions, these regions are linked by binary comparisons with selected countries in each region to a partner in another region. ${ }^{42}$ In contrast, the PPPs reported by ECLAC were based on a representative basket for each Latin American country. ${ }^{43}$

OxLAD also contains new and more reliable data for literacy produced by Shane and Barbara Hunt for the Thorp volume, which we have since updated and report in Table A4 below. ${ }^{44}$ Literacy is defined in the conventional way, as the percentage of the population of or above a certain age (usually 15) who cannot read and write a simple statement about everyday life, and derives from country censuses. In practice, however, it may refer to the percentage of the population of or above a certain age with less than two years of primary school enrolment, or may even be self-defined. A more accurate measure of educational attainment would be mean years of schooling, but sufficient data pre-1950 to permit a long-run study are simply not available. Shane

\footnotetext{
${ }^{41}$ The Geary-Khamis method was developed by Geary (1958), and further refined by Khamis (1972).

${ }^{42}$ See Maddison (1995), p. 163, also Heston and Aten (2002).

${ }^{43}$ For further details on the ECLAC PPP methodology, see Economic Commission for Latin America (1963).

${ }^{44}$ The complete data set may be downloaded with accompanying sources and methodological notes (in Spanish and Portuguese as well as English) from http://oxlad.qeh.ox.ac.uk/.
} 
and Barbara Hunt also produced new and more reliable data for life expectancy for the Thorp volume, which we have since updated and show in Table A6. Life expectancy at birth is defined as the number of years a newborn infant would live if prevailing patterns of mortality at the time of birth remained unchanged throughout her lifetime.

Finally, Table A7 shows the available data on urbanisation rates and relative levels of literacy in urban and rural areas. 
Table A1 GDP per capita in 1970 PPP\$, 3-yr average

\begin{tabular}{lccccccccccc}
\hline l970PPP\$ & 1900 & 1910 & 1920 & 1930 & 1940 & 1950 & 1960 & 1970 & 1980 & 1990 & 2000 \\
\cline { 2 - 7 } Argentina & 497 & 658 & 586 & 695 & 723 & 827 & 941 & 1,206 & 1,333 & 1,116 & 1,460 \\
Bolivia & $\ldots$ & $\ldots$ & $\ldots$ & $\ldots$ & $\ldots$ & 236 & 189 & 270 & 337 & 289 & 329 \\
Brazil & 114 & 132 & 155 & 171 & 198 & 235 & 339 & 471 & 801 & 829 & 874 \\
Chile & 284 & 344 & 318 & 502 & 484 & 577 & 679 & 862 & 958 & 1,096 & 1,602 \\
Colombia & 138 & 153 & 201 & 291 & 354 & 421 & 487 & 604 & 816 & 914 & 984 \\
Costa Rica & $\ldots$ & $\ldots$ & 370 & 554 & 524 & 370 & 469 & 655 & 887 & 860 & 998 \\
Dom. Rep. & $\ldots$ & $\ldots$ & $\ldots$ & $\ldots$ & $\ldots$ & 234 & 299 & 376 & 549 & 508 & 685 \\
Ecuador & 68 & 97 & 138 & 163 & 169 & 244 & 290 & 358 & 522 & 513 & 507 \\
El & & & 109 & 178 & 190 & 273 & 329 & 407 & 426 & 367 & 475 \\
Salvador & $\ldots$ & $\ldots$ & & & & & & \\
Guatemala & $\ldots$ & $\ldots$ & 169 & 266 & 413 & 342 & 364 & 453 & 588 & 507 & 583 \\
Haiti & $\ldots$ & $\ldots$ & $\ldots$ & $\ldots$ & $\ldots$ & 118 & 128 & 122 & 159 & 126 & 91 \\
Honduras & $\ldots$ & $\ldots$ & 145 & 265 & 195 & 227 & 250 & 285 & 316 & 317 & 317 \\
Mexico & 240 & 289 & 330 & 311 & 352 & 507 & 628 & 877 & 1,138 & 1,125 & 1,284 \\
Nicaragua & $\ldots$ & $\ldots$ & 115 & 200 & 186 & 219 & 288 & 428 & 299 & 181 & 186 \\
Panama & $\ldots$ & $\ldots$ & $\ldots$ & $\ldots$ & $\ldots$ & 462 & 570 & 890 & 1,053 & 981 & 1,255 \\
Paraguay & $\ldots$ & $\ldots$ & $\ldots$ & $\ldots$ & 304 & 296 & 302 & 352 & 575 & 585 & 560 \\
Peru & 127 & 149 & 177 & 241 & 269 & 331 & 420 & 526 & 622 & 462 & 560 \\
Uruguay & 456 & 566 & 519 & 755 & 664 & 864 & 902 & 963 & 1,148 & 1,131 & 1,457 \\
Venezuela & 94 & 104 & 128 & 364 & 418 & 695 & 961 & 1,198 & 1,230 & 1,024 & 1,015 \\
& & & & & & & & & & & \\
LA6 & 203 & 254 & 268 & 321 & 350 & 436 & 543 & 721 & 975 & 964 & 1,084 \\
LAl3 & 109 & 136 & 238 & 299 & 280 & 313 & 357 & 441 & 544 & 469 & 538 \\
& & & & & & & & & & & \\
US & 1,478 & 1,712 & 1,886 & 2,142 & 2,481 & 3,284 & 3,826 & 5,125 & 6,295 & 7,398 & 8,867 \\
N. Europe & 1,194 & 1,295 & 1,227 & 1,552 & 1,871 & 1,853 & 2,775 & 3,879 & 4,823 & 5,986 & 6,695 \\
S. Europe & 646 & 782 & 848 & 979 & 1,015 & 1,047 & 1,698 & 2,944 & 3,945 & 4,904 & 5,694 \\
Asia & 223 & 242 & 254 & 260 & 264 & 225 & 282 & 337 & 424 & 624 & 823 \\
\hline \hline
\end{tabular}

Notes: Northern Europe refers to United Kingdom, Germany, and France. Southern

Europe refers to Italy and Spain. Asia refers to India, Indonesia, and Korea. 3-year averages except for 1900, 2000: 1900-2, 1998-2000, respectively; and 1920 for LA13: 1920-2. GDP figures in constant local currency units rescaled to 1970 prices before conversion to purchasing power parity (PPP) prices using 1970 adjustment factors given in Table A3. LA13 for 1900, 1910: Ecuador, Peru only; 1920, 1930: Costa Rica, El Salvador, Guatemala, Honduras, Nicaragua only; 1940: LA13 excluding Bolivia, Dominican Republic, Haiti, Panama, and Peru. GDP in 1970 PPP prices for US calculated by applying index of GDP volume in constant PPP prices to US GDP in 1970; for Europe and Asia calculated by first applying the ratio of country GDP in 1990 PPP prices and US GDP in 1990 PPP prices to US GDP in 1970 to derive GDP 
in 1970 PPP prices for 1970, and then applying index of GDP volume in constant PPP prices. Data for Asia 1900-1910 excludes Korea. Sources: All population data for Latin America are from Astorga, Bergés, and FitzGerald (2003); data for US, Europe, and Asia are from Maddison (1995) for 1900-94; for US and Europe from IMF (2002) and for Asia from World Bank (2004) for 1995-2000. GDP in constant 1970 local currency units for Latin America are from Astorga, Bérges, and FitzGerald (2003); data for US GDP in constant PPP prices from Maddison (1995), for 1900-94 and IMF (2002), for 1995-2000, for Europe from Maddison (1995), for 1900-94 and IMF (2002) for 1995-2000; for Asia from Maddison (1995), for 1900-94, and World Bank (2004), with PPP conversion factors from World Bank (2004), for 1995-2000. Data on Cuban GDP are available as from 1985 only: see ECLAC $(1999,2001)$ and ONEC (2000). Between 1959 and 1984, official sources of Cuban economic performance report only Gross/Global Material Product (GMP) figures, in accordance with Cuba's use of the Soviet Material Product System (MPS). Estimating GDP from GMP figures is complicated by the fact that the latter excludes non-material services and takes a 'gross value' rather than a 'value-added' approach; on this see Brundenius (1984), pp. 19-40, Mesa-Lago (1981), pp. 39, 199-201, and Mesa-Lago (2000), pp. 564-5. 
Table A2 GDP purchasing power parities and exchange rates

(national currency units per dollar and ratio)

\begin{tabular}{lcccccc}
\hline \hline & $\begin{array}{c}\text { Exchange } \\
\text { rate }\end{array}$ & $\begin{array}{c}\text { Exchange } \\
\text { rate }\end{array}$ & ICP IVa & ICP IVb & AH & ECLAC \\
& 1980 & 1970 & 1980 & 1980 & 1980 & 1970 \\
\hline $\begin{array}{l}\text { GDP purchasing power parities } \\
\text { Argentina (pesos }\end{array}$ & $1,837.16$ & 3.79 & $2,709.0$ & $2,604.0$ & $2,596.0$ & 2.95 \\
argentinos) & & & & & & \\
Brazil (new cruzeiros) & 52.69 & 4.59 & 30.6 & 32.5 & 32.4 & 4.14 \\
Chile (new pesos) & 39.00 & 0.01 & 28.8 & 26.7 & 26.5 & 0.01087 \\
Colombia(pesos) & 47.28 & 18.44 & 23.1 & 22.0 & 21.6 & 10.68 \\
Mexico (silver pesos) & 22.97 & 12.49 & n.a. & n.a. & 13.4 & 8.88 \\
Venezuela (bolivares) & 4.29 & 4.45 & 3.6 & 3.14 & 3.1 & 3.96 \\
& & & & & & \\
PPP-exchange rate deviation indices & & & & & \\
Argentina & & & 0.68 & 0.71 & 0.71 & 1.28 \\
Brazil & & & 1.72 & 1.62 & 1.63 & 1.11 \\
Chile & & 1.35 & 1.46 & 1.47 & 1.04 \\
Colombia & & 2.05 & 2.15 & 2.19 & 1.73 \\
Mexico & & $\ldots$ & $\ldots$ & 1.71 & 1.41 \\
Venezuela & & 1.19 & 1.37 & 1.38 & 1.12 \\
& & & & & & \\
\hline \hline
\end{tabular}

Sources and notes: There is some discrepancy between Hofman and Maddison ICP

IV PPPs, so both are reported. AH and ICP IV a PPPs are from Hofman (2000), p.

80; ICP IVb is from Maddison (1995), p. 177; ECLAC is from ECLAC (1978), p. 8. 
Table A3 PPP adjustment of GDP per capita, 1970

\begin{tabular}{lcccc}
\hline \hline & \multicolumn{4}{c}{ GDP per capita in 1970 Conversion rates in 1970 } \\
\hline & US\$ & PPP & OER & PPPR \\
& $(1)$ & $(2)$ & $(3)$ & $(4)$ \\
Argentina & 940 & 1,208 & 3.79 & 2.95 \\
Bolivia & 206 & 272 & 11.90 & 9.03 \\
Brazil & 418 & 464 & 4.59 & 4.14 \\
Chile & 819 & 850 & 11.28 & 10.87 \\
Colombia & 351 & 606 & 18.44 & 10.68 \\
Costa Rica & 506 & 659 & 6.63 & 5.09 \\
Dom. Rep. & 326 & 375 & 1.00 & 0.87 \\
Ecuador & 244 & 359 & 20.64 & 14.00 \\
El Salvador & 276 & 406 & 2.50 & 1.70 \\
Guatemala & 338 & 450 & 1.00 & 0.75 \\
Haiti & 97 & 121 & 5.00 & 3.99 \\
Honduras & 244 & 279 & 2.00 & 1.75 \\
Mexico & 630 & 886 & 12.49 & 8.88 \\
Nicaragua & 389 & 424 & 7.00 & 6.41 \\
Panama & 673 & 885 & 1.00 & 0.76 \\
Paraguay & 240 & 353 & 126.00 & 85.41 \\
Peru & 420 & 529 & 38.70 & 30.72 \\
Uruguay & 779 & 980 & 250.00 & 198.68 \\
Venezuela & 1,078 & 1,212 & 4.45 & 3.96 \\
& & & & \\
US & 5,070 & 5,070 & 1.00 & 1.00 \\
& & & & \\
\hline \hline
\end{tabular}

Notes: col. 1, GDP per capita in US dollars at current prices in 1970; col. 2, GDP per capita in constant 1970 international PPP dollars in 1970; col. 3, Official nominal exchange rate in 1970, local currency units per US dollar; col. 4, PPP-adjusted exchange rate. Sources: col. 1 and col. 2, as for Table A2; col. 3, Latin America from Astorga, Bergés, and FitzGerald (2003); col. 4, ECLAC (1978), p. 8. 
Table A4 Literacy rates

\begin{tabular}{|c|c|c|c|c|c|c|c|c|c|c|c|}
\hline Percent & 1900 & 1910 & 1920 & 1930 & 1940 & 1950 & 1960 & 1970 & 1980 & 1990 & 2000 \\
\hline Argentina & 51 & 60 & 68 & 75 & 82 & 88 & 91 & 93 & 94 & 96 & 97 \\
\hline Bolivia & 19 & 20 & 23 & 25 & 28 & 32 & 44 & 58 & 69 & 78 & 86 \\
\hline Brazil & 35 & 35 & 35 & 40 & 44 & 49 & 60 & 68 & 76 & 81 & 85 \\
\hline Chile & 44 & 53 & 63 & 75 & 73 & 79 & 84 & 88 & 92 & 94 & 96 \\
\hline Colombia & 34 & 39 & 44 & 52 & 57 & 62 & 70 & 78 & 84 & 89 & 92 \\
\hline Costa Rica & 36 & 47 & 58 & 67 & 73 & 79 & 83 & 88 & 92 & 94 & 96 \\
\hline Cuba & 46 & 57 & 64 & 71 & 76 & 78 & 79 & 89 & 93 & 95 & 97 \\
\hline Dom. Rep. & $\ldots$ & $\cdots$ & 29 & 26 & 30 & 43 & 65 & 67 & 74 & 79 & 84 \\
\hline Ecuador & 33 & 38 & 42 & 46 & 51 & 56 & 66 & 74 & 82 & 87 & 92 \\
\hline$E l$ & 26 & 27 & 27 & 28 & 35 & 42 & 48 & 58 & 66 & 73 & 79 \\
\hline \multicolumn{12}{|l|}{ Salvador } \\
\hline Guatemala & 12 & 13 & 15 & 19 & 24 & 29 & 36 & 45 & 53 & 61 & 69 \\
\hline Haiti & 8 & 8 & 8 & 9 & 9 & 11 & 16 & 22 & 31 & 40 & 50 \\
\hline Honduras & 28 & 30 & 32 & 34 & 35 & 40 & 45 & 53 & 62 & 69 & 75 \\
\hline Mexico & 24 & 30 & 35 & 36 & 46 & 61 & 65 & 75 & 82 & 88 & 91 \\
\hline Nicaragua & $\ldots$ & $\ldots$ & 39 & 39 & 39 & 38 & 47 & 57 & 61 & 65 & 67 \\
\hline Panama & 17 & 27 & 42 & 46 & 59 & 67 & 73 & 79 & 85 & 89 & 92 \\
\hline Paraguay & 31 & 38 & 45 & 52 & 59 & 66 & 73 & 80 & 86 & 90 & 93 \\
\hline Peru & 24 & 29 & 33 & 37 & 42 & 51 & 60 & 72 & 80 & 86 & 90 \\
\hline Uruguay & 59 & 65 & 71 & 76 & 81 & 86 & 90 & 93 & 95 & 97 & 98 \\
\hline Venezuela & 28 & 29 & 32 & 36 & 42 & 51 & 62 & 77 & 84 & 89 & 93 \\
\hline LA6 & 33 & 38 & 42 & 47 & 53 & 60 & 68 & 75 & 81 & 86 & 89 \\
\hline LA13 & 25 & 28 & 32 & 35 & 40 & 46 & 55 & 64 & 71 & 77 & 82 \\
\hline$U S$ & 89 & 92 & 94 & 95 & 96 & 97 & 98 & 99 & 100 & 100 & 99 \\
\hline
\end{tabular}

Notes: Reported figures come from census data, interpolations between census years. LA13 for 1900, 1910 exclude Dominican Republic and Nicaragua. Sources: All literacy figures for 1900-60 are from Astorga, Bergés, and FitzGerald (2003). See Astorga, Bergés, and FitzGerald (2003) for further discussion of primary sources and splicing methods. 
Table A5 Life Expectancy at birth

\begin{tabular}{lccccccccccc}
\hline \hline Years & 1900 & 1910 & 1920 & 1930 & 1940 & 1950 & 1960 & 1970 & 1980 & 1990 & 2000 \\
\cline { 2 - 5 } & 39 & 44 & 49 & 53 & 56 & 61 & 65 & 67 & 70 & 72 & 73 \\
Bolivia & 26 & 28 & 31 & 33 & 36 & 40 & 43 & 46 & 52 & 58 & 62 \\
Brazil & 29 & 31 & 32 & 34 & 37 & 43 & 55 & 59 & 63 & 66 & 68 \\
Chile & 29 & 30 & 31 & 35 & 38 & 49 & 57 & 62 & 69 & 74 & 75 \\
Colombia & 29 & 31 & 32 & 34 & 38 & 49 & 57 & 61 & 66 & 69 & 71 \\
Costa Rica & 32 & 33 & 37 & 42 & 49 & 56 & 62 & 67 & 72 & 76 & 76 \\
Cuba & 32 & 36 & 39 & 42 & 45 & 56 & 64 & 70 & 74 & 74 & 76 \\
Dom. Rep & $\ldots$ & $\ldots$ & $\ldots$ & 26 & 34 & 44 & 52 & 58 & 64 & 69 & 67 \\
Ecuador & $\ldots$ & $\ldots$ & $\ldots$ & $\ldots$ & $\ldots$ & 48 & 53 & 58 & 63 & 68 & 70 \\
El & $\ldots$ & $\ldots$ & 28 & 29 & 36 & 44 & 50 & 57 & 57 & 66 & 70 \\
Salvador & $\ldots$ & $\ldots$ & & & & & \\
Guatemala & 24 & 24 & 25 & 25 & 29 & 38 & 46 & 52 & 58 & 63 & 65 \\
Haiti & $\ldots$ & $\ldots$ & $\ldots$ & $\ldots$ & $\ldots$ & 36 & 42 & 47 & 52 & 56 & 53 \\
Honduras & $\ldots$ & $\ldots$ & 29 & 34 & 36 & 39 & 46 & 53 & 60 & 67 & 66 \\
Mexico & 25 & 28 & 34 & 34 & 39 & 48 & 57 & 61 & 67 & 71 & 73 \\
Nicaragua & $\ldots$ & $\ldots$ & 24 & 28 & 34 & 39 & 47 & 54 & 59 & 64 & 68 \\
Panama & $\ldots$ & $\ldots$ & $\ldots$ & 36 & 42 & 50 & 61 & 65 & 70 & 72 & 74 \\
Paraguay & 25 & 29 & 33 & 38 & 42 & 48 & 55 & 61 & 67 & 69 & 70 \\
Peru & $\ldots$ & $\ldots$ & $\ldots$ & $\ldots$ & 37 & 40 & 48 & 54 & 60 & 66 & 69 \\
Uruguay & 49 & 52 & 52 & 50 & 58 & 66 & 68 & 69 & 70 & 72 & 74 \\
Venezuela & 28 & 29 & 31 & 32 & 38 & 51 & 60 & 65 & 68 & 71 & 73 \\
& & & & & & & & & & & \\
LA6 & 29 & 31 & 35 & 37 & 40 & 48 & 57 & 61 & 65 & 69 & 70 \\
LA13 & 31 & 33 & 33 & 34 & 38 & 43 & 50 & 55 & 60 & 66 & 67 \\
US & & & & & & & & & & & \\
\hline \hline
\end{tabular}

Sources: Estimates of life expectancy reported in OxLAD were produced by Barbara and Shane Hunt with data from Arriaga (1968), Palloni (1990), and CELADE (1996). To complete the series for the aggregate of Latin America in 1945, Ecuador and Haiti figures in this year are obtained by subtracting one year from the figure of 1950 . LA13 for 1900: Bolivia, Costa Rica, Guatemala, Paraguay, and Uruguay only; 1920: Bolivia, Costa Rica, El Salvador, Guatemala, Honduras, Nicaragua, Paraguay, and Uruguay only; 1930: Bolivia, Costa Rica, Dominican Republic, El Salvador, Guatemala, Honduras, Nicaragua, Paraguay, Panama, and Uruguay only; 1940: Bolivia, Costa Rica, Dominican Republic, El Salvador, Guatemala, Honduras, Nicaragua, Paraguay, Panama, Peru, and Uruguay only. 


\begin{tabular}{lccccccccccc}
\hline \hline & 1900 & 1910 & 1920 & 1930 & 1940 & 1950 & 1960 & 1970 & 1980 & 1990 & 2000 \\
\hline Argentina & 0.34 & 0.41 & 0.46 & 0.51 & 0.56 & 0.61 & 0.65 & 0.68 & 0.71 & 0.71 & 0.74 \\
Bolivia & $\ldots$ & $\ldots$ & $\ldots$ & $\ldots$ & $\ldots$ & 0.24 & 0.28 & 0.36 & 0.45 & 0.50 & 0.56 \\
Brazil & 0.14 & 0.16 & 0.18 & 0.21 & 0.25 & 0.31 & 0.43 & 0.50 & 0.58 & 0.61 & 0.64 \\
Chile & 0.22 & 0.28 & 0.31 & 0.40 & 0.40 & 0.49 & 0.56 & 0.62 & 0.68 & 0.72 & 0.75 \\
Colombia & 0.15 & 0.19 & 0.22 & 0.28 & 0.33 & 0.42 & 0.49 & 0.56 & 0.62 & 0.66 & 0.69 \\
Costa Rica & $\ldots$ & $\ldots$ & 0.35 & 0.41 & 0.46 & 0.51 & 0.57 & 0.63 & 0.69 & 0.72 & 0.73 \\
Cuba & $\ldots$ & $\ldots$ & $\ldots$ & $\ldots$ & $\ldots$ & $\ldots$ & $\ldots$ & $\ldots$ & $\ldots$ & $\ldots$ & $\ldots$ \\
Dom. Rep. & $\ldots$ & $\ldots$ & $\ldots$ & $\ldots$ & $\ldots$ & 0.30 & 0.43 & 0.48 & 0.56 & 0.60 & 0.62 \\
Ecuador & $\ldots$ & $\ldots$ & $\ldots$ & $\ldots$ & $\ldots$ & 0.36 & 0.43 & 0.50 & 0.58 & 0.62 & 0.64 \\
El & & & & & & & & & & & \\
Salvador & $\ldots$ & $\ldots$ & 0.13 & 0.15 & 0.22 & 0.30 & 0.37 & 0.45 & 0.48 & 0.54 & 0.60 \\
Guatemala & $\ldots$ & $\ldots$ & $\ldots$ & 0.12 & 0.18 & 0.24 & 0.30 & 0.38 & 0.46 & 0.51 & 0.55 \\
Haiti & $\ldots$ & $\ldots$ & $\ldots$ & $\ldots$ & $\ldots$ & 0.11 & 0.16 & 0.21 & 0.28 & 0.32 & 0.31 \\
Honduras & $\ldots$ & $\ldots$ & 0.17 & 0.22 & 0.21 & 0.26 & 0.32 & 0.39 & 0.46 & 0.52 & 0.54 \\
Mexico & 0.13 & 0.17 & 0.23 & 0.23 & 0.30 & 0.42 & 0.50 & 0.57 & 0.64 & 0.68 & 0.71 \\
Nicaragua & $\ldots$ & $\ldots$ & $\ldots$ & 0.18 & 0.21 & 0.25 & 0.34 & 0.43 & 0.45 & 0.47 & 0.50 \\
Panama & $\ldots$ & $\ldots$ & $\ldots$ & $\ldots$ & $\ldots$ & 0.45 & 0.54 & 0.61 & 0.66 & 0.69 & 0.72 \\
Paraguay & $\ldots$ & $\ldots$ & $\ldots$ & $\ldots$ & 0.35 & 0.41 & 0.47 & 0.53 & 0.62 & 0.65 & 0.66 \\
Peru & $\ldots$ & $\ldots$ & $\ldots$ & $\ldots$ & $\ldots$ & 0.32 & 0.41 & 0.49 & 0.56 & 0.59 & 0.64 \\
Uruguay & $\ldots$ & $\ldots$ & $\ldots$ & $\ldots$ & 0.56 & 0.63 & 0.66 & 0.68 & 0.70 & 0.72 & 0.75 \\
Venezuela & 0.11 & 0.12 & 0.16 & 0.23 & 0.29 & 0.42 & 0.52 & 0.62 & 0.66 & 0.68 & 0.70 \\
& & & & & & & & & & & \\
LA6 & 0.17 & 0.21 & 0.24 & 0.28 & 0.32 & 0.40 & 0.49 & 0.56 & 0.62 & 0.65 & 0.68 \\
LAl3 & $\ldots$ & $\ldots$ & $\ldots$ & 0.18 & 0.31 & 0.31 & 0.39 & 0.46 & 0.52 & 0.56 & 0.59 \\
US & & & & & & & & & & & \\
\hline \hline
\end{tabular}

Notes: LA13 for 1920, 1930: Costa Rica, El Salvador, Guatemala, Honduras, and

Nicaragua only. Sources: as for Tables A1, A4, and A5. 
Table A7 Urbanisation in LA6 countries, and comparison of literacy in rural and

urban areas, $1900-2000$

\begin{tabular}{|c|c|c|c|c|c|c|}
\hline & & (percer & & & & \\
\hline Urbanisation ratio & Argentina & Brazil & Chile & Colombia & Mexico & Venezuela \\
\hline $1900-10$ & 29 & 10 & 20 & 6 & 6 & \\
\hline $1911-20$ & 30 & 10 & 23 & 7 & & 17 \\
\hline $1921-30$ & 38 & 15 & 38 & 15 & 15 & 24 \\
\hline $1931-40$ & & & & & & \\
\hline $1941-50$ & 62 & & & & & 28 \\
\hline $1951-60$ & & 36 & 61 & 43 & 43 & 48 \\
\hline $1961-70$ & 76 & 51 & 72 & 54 & 55 & 67 \\
\hline $1971-80$ & 81 & 62 & 79 & 61 & 63 & 76 \\
\hline $1981-90$ & 85 & 71 & 83 & 67 & 70 & 82 \\
\hline 1991-2000 & 88 & 79 & 84 & 72 & 74 & 86 \\
\hline $\begin{array}{l}\text { Ratio of urban-rurc } \\
\text { literacy }\end{array}$ & & & & & & \\
\hline $1900-10$ & & & 187 & & & \\
\hline $1911-20$ & & & & & & \\
\hline $1921-30$ & & & & & & \\
\hline $1931-40$ & & & & 185 & & \\
\hline $1941-50$ & 119 & 222 & & & & 252 \\
\hline $1951-60$ & 115 & & 137 & 157 & 154 & \\
\hline $1961-70$ & & 172 & 126 & 145 & 138 & 212 \\
\hline $1971-80$ & 112 & 155 & & 136 & & \\
\hline $1981-90$ & & & 120 & 121 & & 142 \\
\hline $1991-2000$ & 110 & & 113 & & & 126 \\
\hline
\end{tabular}

Sources and notes: Urbanisation data for Argentina: Calculated from Laks (1971) p. 23 and comprise populations of Buenos Aires, Rosario, Córdoba, Tucumán, La Plata, Santa Fé, Mendoza, Bahia Blanca, Paraná, Corrientes, and Salta, for 1916 and 1920 except datum for 1909 estimated by applying ratio of population of Buenos Aires in 1909 (reported in Scobie 1978 p. 427-9) and 1895 to other cities in 1895; Brazil:

Calculated from Conniff et al (1971) p. 37, for Rio de Janeiro, São Paulo, Salvador, Recife, Belém, Pôrto Alegre, Niteroi, Curitiba, Manaus, Maceió, and Fortaleza for 1900 and 1920; Chile: Calculated from Conniff (1971) p. 54, for Santiago, Valparaiso, Concepción, Antofagasto, Iquique, and Tolca for 1907, 1920; Colombia: Calculated from Friedel and Jimenez (1971) p. 62, for Bogotá, Medellín, Barranquilla, Cartagena, Cali, and Manizales for 1905 and 1912 ; Mexico: Calculated from Wibel and de la Cruz (1971) p. 95, for Mexico City, Guadalajara, Puebla, Monterrey, Mérida, San Luis Potosí, Vera Cruz, and Guanajuato for 1900, 1910, and 1921. Data for 1930 are calculated from Scobie (1986) p. 159. Data from 1940s onwards and for Venezuela from 1920 onwards are calculated from Astorga, Bergés and FitzGerald (2003). Urban-rural literacy data are unpublished estimates provided by Shane and Barbara Hunt from the following country censuses: Argentina, 1947, 1960, 1980; Brazil, 1950, 1960, 1970, 1980; Chile, 1952, 1960, 1970, 1982; Colombia, 1951, 1964, 1973; Mexico, 1960, 1970; and Venezuela, 1950, 1961, 1971, 1981. 


\section{References}

Adelman, J., 'Socialism and Democracy in Argentina in the Age of the Second International', Hispanic American History Review LXXII 2 (1992), pp. 21-38.

Arriaga, E.E., New Life Tables for Latin American Populations in the Nineteenth and Twentieth Centuries (Berkeley, CA, 1968).

Astorga, P., Bérges, AR. and FitzGerald, E.V.K., 'The Oxford Latin American Economic History Database', The Latin American Centre at Oxford University, (Oxford, 2003). Available from http://oxlad.qeh.ox.ac.uk/.

Astorga, P., Bergés, A.R. and FitzGerald, E.V.K., 'Productivity Growth in Latin America during the Twentieth Century', Oxford University Discussion Papers in Economic and Social History 52 (Oxford, 2004). Available from http://www.nuff.ox.ac.uk/Economics/History/Paper52/52fitzgerald.pdf/.

_- 'Endogenous Growth and Exogenous Shocks in Latin America during the Twentieth Century,' Oxford University Discussion Papers in Economic and Social History 57 (Oxford, 2005). Available from http://www.nuff.ox.ac.uk/Economics/History/paper57/57astorga.pdf/.

Baumol, W.J., 'Productivity Growth, Convergence and Welfare: What the Long-Run Data Show', American Economic Review 765 (1986), pp. 1072-85.

Brundenius, C., Revolutionary Cuba: The Challenge of Economic Growth with Equity (Boulder, CO, 1984).

Bulmer-Thomas, V., The Economic History of Latin America since Independence (Cambridge, 1994).

Cárdenas, E., Ocampo, J.A. and Thorp, R., eds. The Export Age: The Latin American Economies in the Nineteenth and Early Twentieth Centuries 1. (Basingstoke, 2000a).

eds. Industrialization and the State in Latin America: The Postwar Years 3. (Basingstoke, 2000b).

Centro Latinoamericano de Demografía (CELADE), Boletín Demográfico 2958 (Santiago de Chile, 1996).

Conniff, M.L., M. Hendrix, and S. Nohlgren, 'Brazil', in R.M. Morse, ed. The Urban Development of Latin America, 1750-1920 (Stanford, 1971), pp. 36-52.

Conniff, M.L., 'Chile', in R.M. Morse, ed. The Urban Development of Latin America, 1750-1920 (Stanford, 1971), pp. 53-60. 
Crafts, N.F.R., 'The Human Development Index and Changes in Standards of Living: Some Historical Comparisons,' European Review of Economic History 13 (1997), pp. 299-332.

_- 'The Human Development Index, 1870-1999: Some Revised Estimates,' European Review of Economic History 63 (December, 2002), pp. 395-405.

De Gregorio, J., 'Economic Growth in Latin America', IMF Working Paper Series WP/91/71 (Washington DC, 1991).

Dornbusch, R. and Edwards, S., eds. The Macroeconomics of Populism in Latin America (Chicago, 1991).

Easterlin, R.A., 'Life during Growth: International Evidence on Quality of Life and Per Capita Income', World Bank Working Paper Series 2110 (Washington DC, 1999).

— ' 'The Worldwide Standard of Living since 1800', Journal of Economic Perspectives 141 (2000), pp. 7-26.

Easterly, W., Loayza, N. and Montiel, P., 'Has Latin America's Post-Reform Growth Been Disappointing?', World Bank Policy Research Working Papers 1708 (Washington DC, 1997).

Economic Commission for Latin America and the Caribbean, Measurement of Price Levels and the Purchasing Power of Currencies in Latin America, 1960-1962 E/CN.12/653 (Mar del Plata Argentina, May 1963). - (ECLAC CE), Series Históricas del Crecimiento de América Latina, Cuadernos Estadísticos de la CEPAL 3 (Santiago de Chile, 1978).

(ECLAC SYLA), Statistical Yearbook for Latin America 1998 (New York, 1999).

—, Statistical Yearbook for Latin America 2000 (New York, 2001).

—, Balance Preliminar de la Economía de América Latina y el Caribe (Santiago de Chile, 2003).

Edwards, S., Crisis and Reform in Latin America: From Despair to Hope (New York, 1995).

Fajnzylber, P. and Lederman, D., 'Economic Reforms and Total Factor Productivity Growth in Latin America and the Caribbean (1950-95): An Empirical Note', World Bank Policy Research Working Papers 2114 (Washington DC, 1999).

Ffrench-Davis, R., Reforming the Reforms in Latin America: Macroeconomics, Trade, Finance (London, 2000). 
FitzGerald, E.V.K., 'The Financial Constraint on Relative Autonomy: The State and Capital Accumulation in Mexico, 1940-82', in C. Anglade and C. Fortin, eds, The State and Capital Accumulation in Latin America 1 (Pittsburgh, PA, 1985).

_ , 'ECLA and the Theory of Import-Substituting Industrialisation in Latin America', in E. Cárdenas, J. A. Ocampo and R. Thorp, eds, Industrialisation and the State in Latin America 3 (Basingstoke, 2000), pp. 58-97.

FitzGerald, V. and R. Thorp, eds, Economic Doctrines in Latin America: Origins, Embedding and Evolution (Basingstoke, 2005)

Friedel, E. and M.F. Jimenez, 'Colombia', in R.M. Morse, ed., The Urban Development of Latin America, 1750-1920 (Stanford, 1971), pp. 61-76.

Geary, R.C., 'A Note on the Comparison of Exchange Rates and Purchasing Power Parities between Countries', Journal of the Royal Statistical Society 1211 (1958), 97-99.

Heston, A. and Aten, B., 'Linking Country Groups in International Real Product and Purchasing Power Comparisons,' Conference on the International Comparison Program (Washington DC, 11-14 March 2002). Available from http://pwt.econ.upenn.edu/papers/heston-atenwb.pdf.

Heston, A.W. and Summers, R., 'The Penn World Table (Mark 5): An Expanded Set of International Comparisons, 1950-1988', Quarterly Journal of Economics 1062 (1991), pp. 327-68.

Hilton, S., 'Vargas and Brazilian Economic Development, 1930-45: A Reappraisal of His Attitudes Towards Industrialisation and Planning', Journal of Economic History XXXV 4 (1975), pp. 754-78.

Hofman, A., Latin American Economic Development: A Causal Analysis in Historical Perspective, Groningen Growth and Development Centre Monograph Series 3 (Groningen, Netherlands, 1998).

- The Economic Development of Latin America in the Twentieth Century (Cheltenham, 2000).

International Monetary Fund (IMF IFS), International Financial Statistics CD-ROM (Washington DC, 2002).

Katz, J. and Kosacoff, B., 'Import-Substituting Industrialization in Argentina, 19401980: Its Achievements and Shortcomings', in E. Cárdenas, J. A. Ocampo and R. Thorp, eds., Industrialization and the State in Latin America: The Postwar Years 3 (Basingstoke, 2000), pp. 282-313.

Khamis, S.H., 'A New System of Index Numbers for National and International Purposes', Journal of the Royal Statistical Society 1351 (1972), pp. 96-121. 
Knight, A., 'The Working Class and the Mexican Revolution, 1900-1920', Journal of Latin American Studies XVI 1 (1984), pp. 51-79.

Laks, N., 'Argentina', in R.M. Morse, ed., The Urban Development of Latin America, 1750-1920 (Stanford, 1971), pp. 22-35.

Lustig, N., 'Equity and Growth in Mexico', in S. Teitel, ed., Towards a New

Development Strategy for Latin America: Pathways from Hirschman's Thought (Washington DC, 1992), pp. 219-58.

Maddison, A., Monitoring the World Economy, 1920-1992 (Paris, 1995).

—, The World Economy: A Millennial Perspective (Paris, 2001).

Meade, T., "'Living Worse and Costing More": Resistance and Riot in Rio de Janeiro, 1890-1917', Journal of Latin American Studies XXI 3 (1989), pp. 241-66.

Mesa-Lago, C., The Economy of Socialist Cuba: A Two-Decade Appraisal (Albuquerque, 1981).

—, Market, Socialist, and Mixed Economies (London, 2000).

Meyer, C., F. Ramirez and Y. Soysul (1992) 'World expansion of mass education, 1970-80’ Sociology of Education 65(2) (1992), pp 128-149

Mitchell, B.R., International Historical Statistics: The Americas, 1750-1993 (Basingstoke, 1998).

Offer, A., 'Economic Welfare Measurements and Human Well-Being', in P.A. David and M. Thomas, eds, The Economic Future in Historical Perspective (Oxford, 2003).

Oficina Nacional de Estadísticas de Cuba (ONEC), Anuario Estadístico de Cuba, Oficina Nacional de Estadísticas de Cuba, http://www.camaracuba.cubaweb.cu/TPHabana/Estadisticas2000/estadisticas20 00.htm (2000).

Palloni, A., 'Fertility and Mortality Decline in Latin America', in S. H. Preston, ed., World Population: Approaching the Year 2000. Annals of the American Academy of Political and Social Science 510 (London, 1990), 126-44.

Portantiero, J.C., 'Political and Economic Crisis in Argentina', in G. Di Tella and R. Dornbusch, eds., The Political Economy of Argentina, 1946-83 (Basingstoke, 1989).

Program to Promote Educational Reform in Latin America and the Caribbean (PREAL), Lagging Behind: A Report Card on Education in Latin America 6 (Santiago de Chile, 2001). Available from http://www.thedialogue.org/publications/preal/lagging.pdf. 
Riley, James C., Rising Life Expectancy: A Global History (New York, 2001).

Sachs, J.D. and Warner, A.M., 'Economic Reform and the Process of Global Integration', Brookings Papers on Economic Activity (1995), pp. 1-118.

Scobie, J., 'Changing Urban Patterns: The Porteño Case', in R.P. Schaedel, J.E. Hardoy, and N. Scott Kinzer, eds, Urbanization in the Americas from Beginnings to Present (The Hague, 1978), pp. 425-35.

, 'The Growth of Latin American Cities, 1870-1930', in L. Bethell, ed., The Cambridge History of Latin America 4 (Cambridge, 1986), pp. 233-66.

Shome, P. 'Taxation in Latin America: Structural Trends and the Impact of Administration' International Monetary Fund Working Paper WP/99/19 (Washington DC, 1999)

Stallings, B. and W. Peres, Growth, Employment and Equity: The Impact of the Economic Reforms in Latin America and the Caribbean (Washington DC, 2000).

Szreter, S. and G. Mooney, 'Urbanization, Mortality, and the Standard of Living Debate: New Estimates of the Expectation of Life at Birth in NineteenthCentury British Cities', Economic History Review 511 (1998), pp 84-112.

Taylor, L., After Neoliberalism: What Next for Latin America? (Chicago, 1999).

Thorp, R., Progress, Poverty and Exclusion: An Economic History of Latin America in the 20th Century (Baltimore, MD, 1998).

ed. Latin America in the 1930s: The Role of the Periphery in World Crisis 2 (Basingstoke, 2000).

United Nations Development Programme (UNDP HDR), Human Development Report 1997: Human Development to Eradicate Poverty (New York, 1997).

- Human Development Report 2002: Deepening Democracy in a Fragmented World (New York, 2002).

Usher, D., The Measurement of Economic Growth (Oxford, 1980).

Wibel, J. and J. de la Cruz, 'Mexico', in R.M. Morse, ed., The Urban Development of Latin America, 1750-1920 (Stanford, 1971), pp. 94-103.

Wilkie, J.W., Statistical Abstract of Latin America (Los Angeles, 2002).

Wils, A., 'On Accelerating the Global Literacy Transition' RASSP Discussion Paper 2002-18 Kennedy School of Government, Harvard University (Cambridge MA, 2002)

World Bank, World Development Indicators CD-ROM (Washington DC, 2004). 


\section{[Figures in Text]}

Figure 1 Trends in per capita income in Latin America over the twentieth century

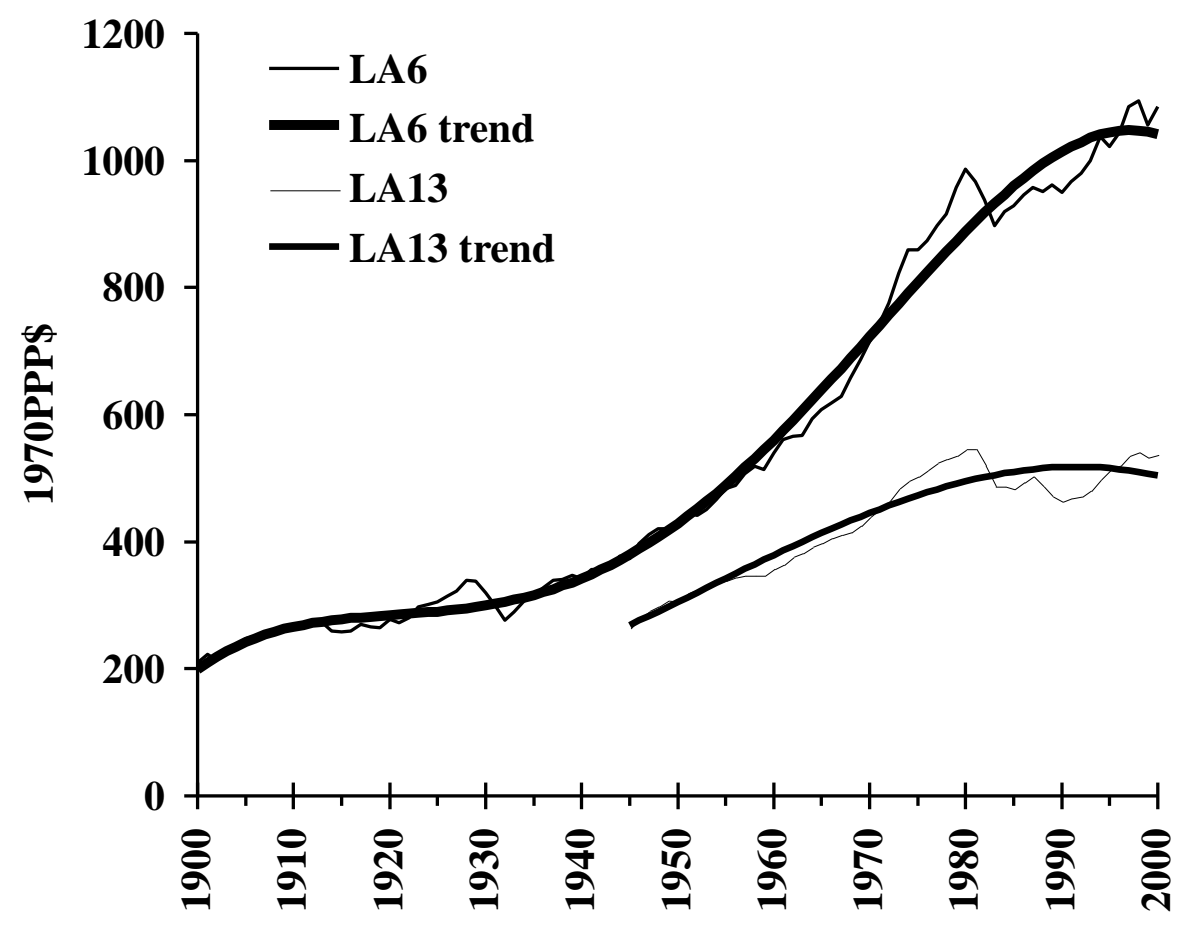

Source: Table A1. 
Figure 2 Literacy in Latin America

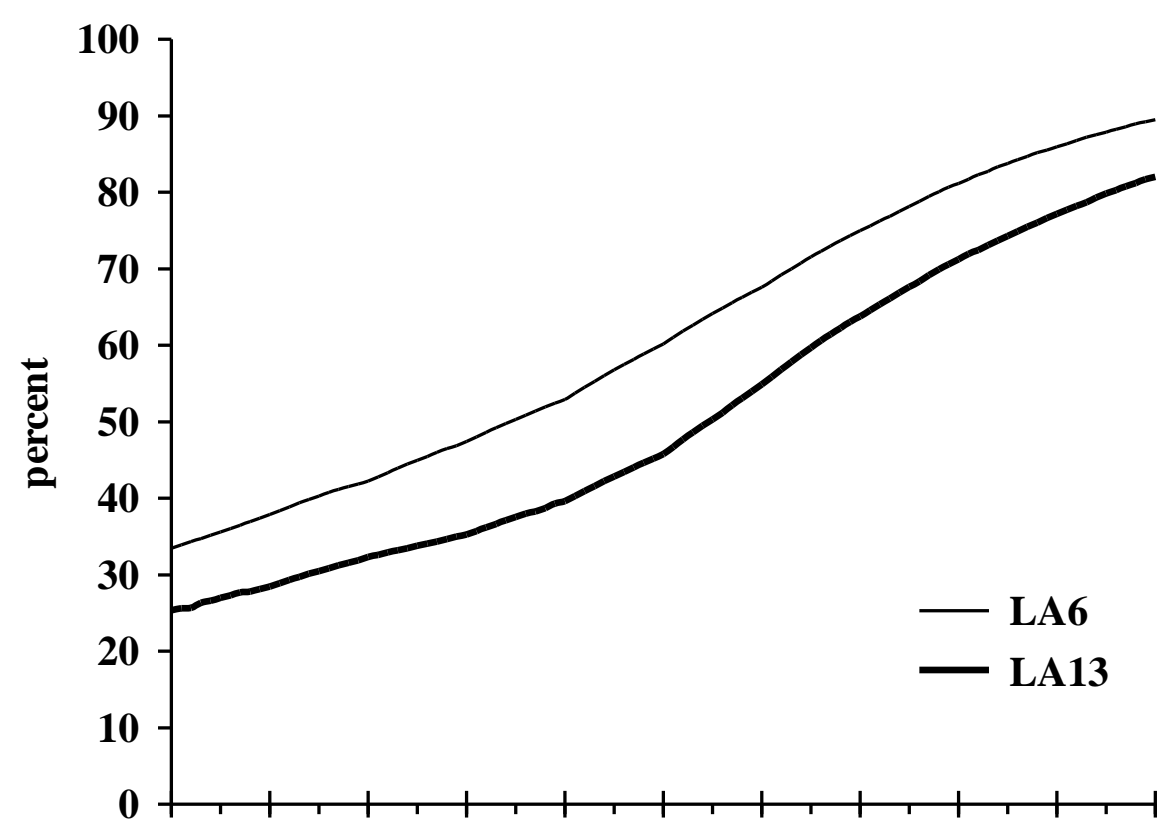

Source: Table A4.

Figure 3 Life expectancy in Latin America

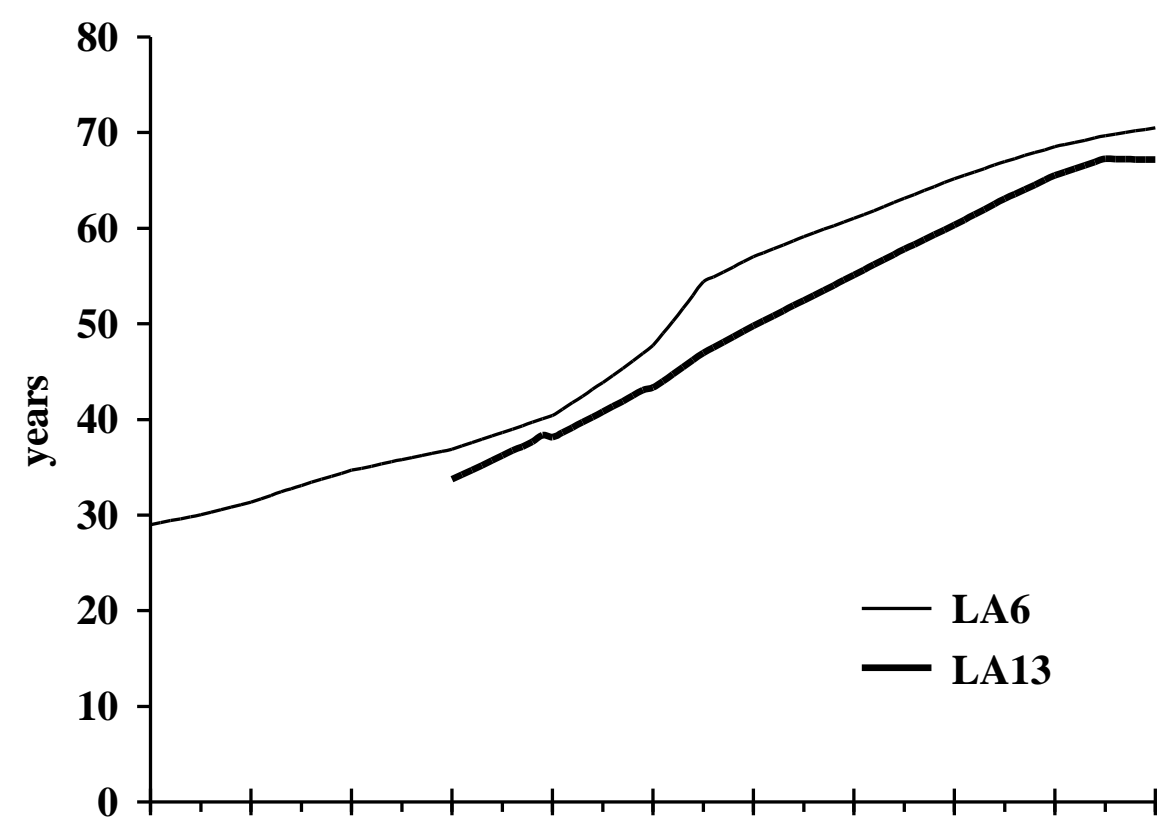

Source: Table A5. 
Figure 4 Historical living standard index (HLSI)

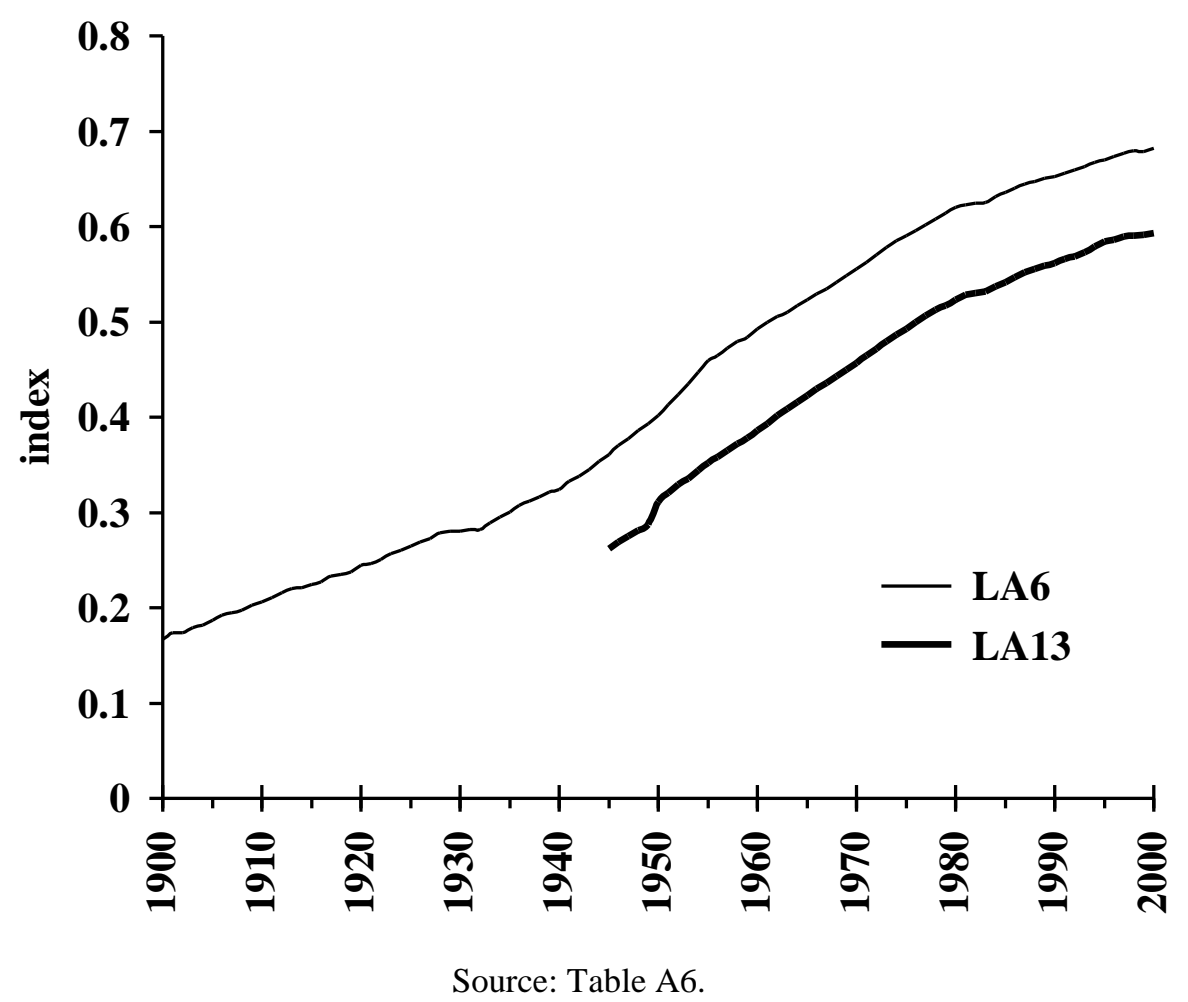

Figure 5 Convergence in living standards within the LA6

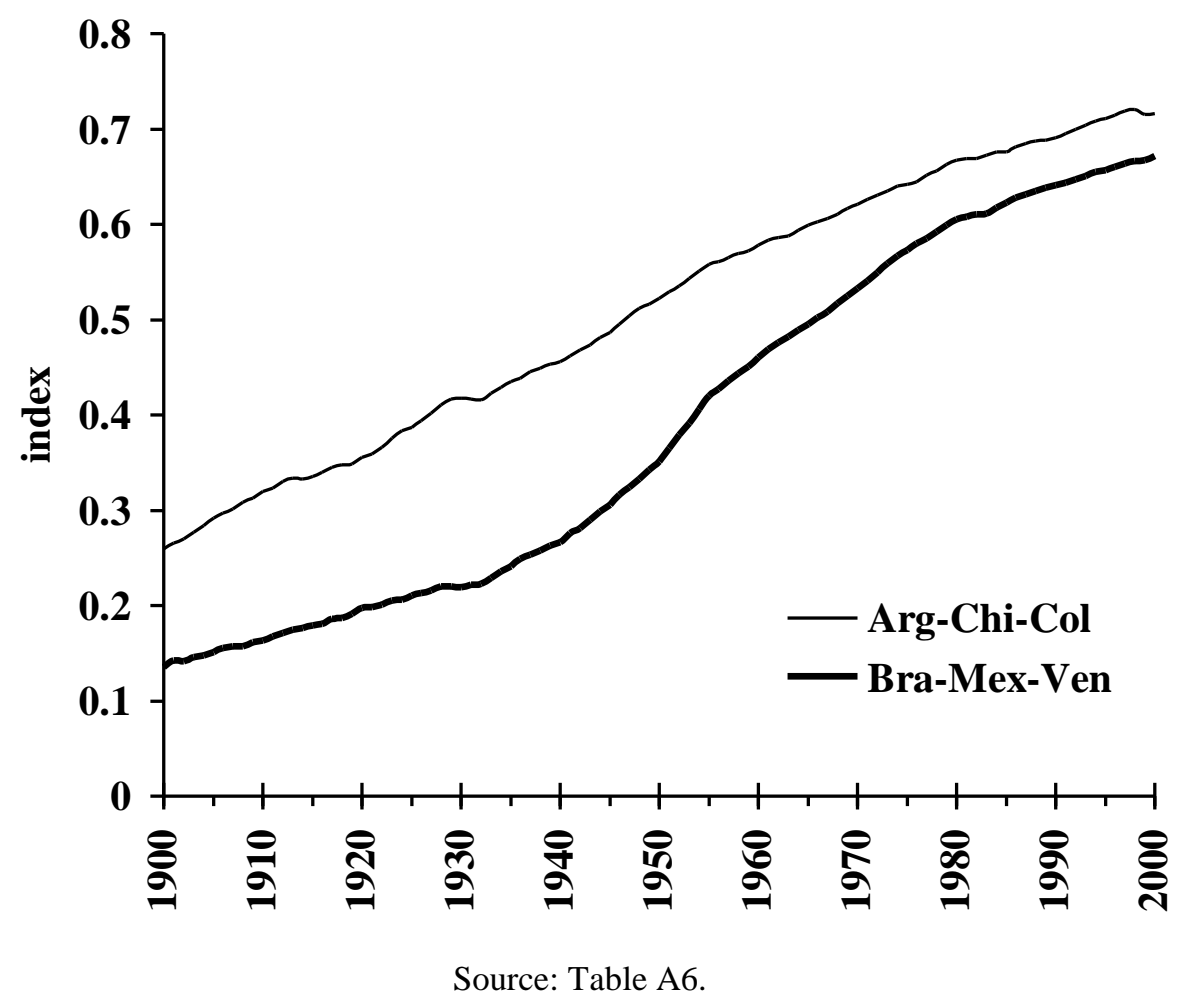


Figure 6a GDP per capita relative to the US

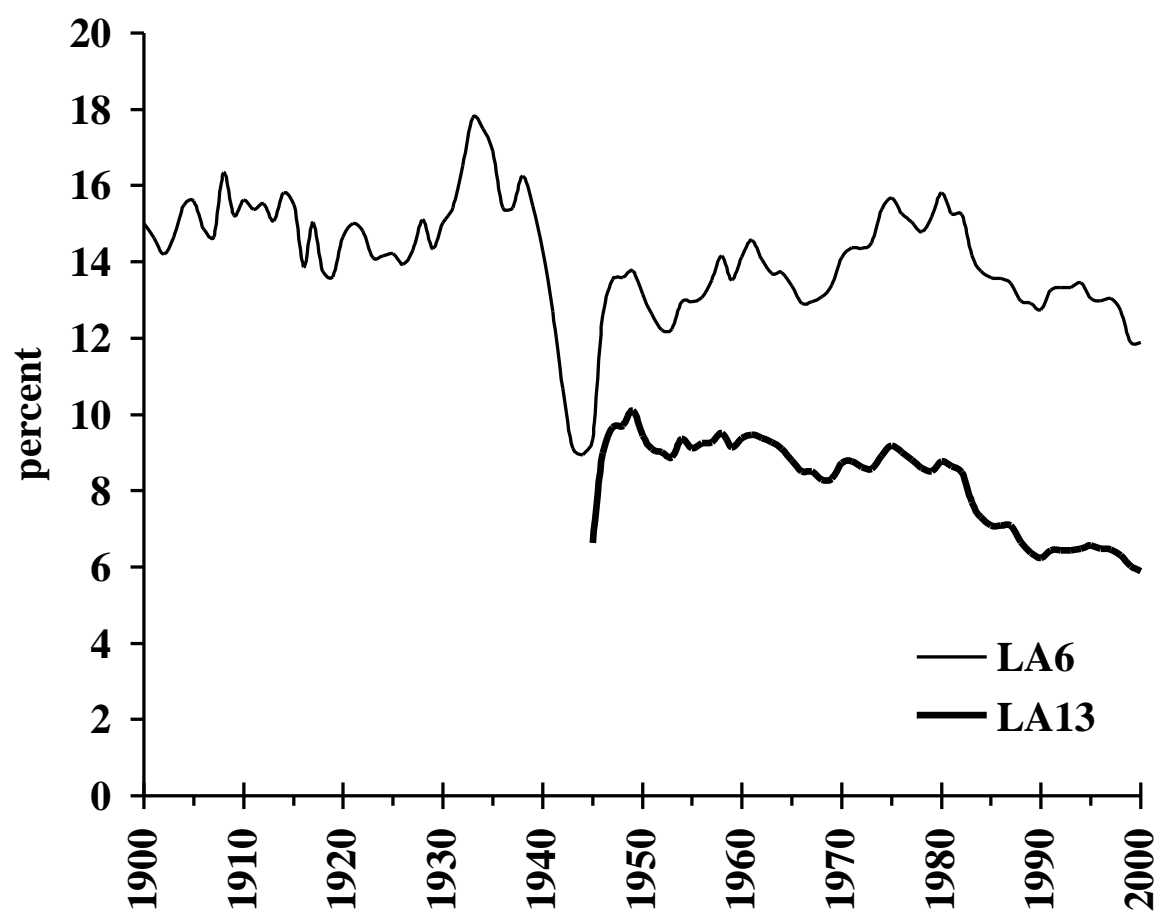

Source: Table A1.

Figure 6b GDP per capita in the LA6, LA13 and the US

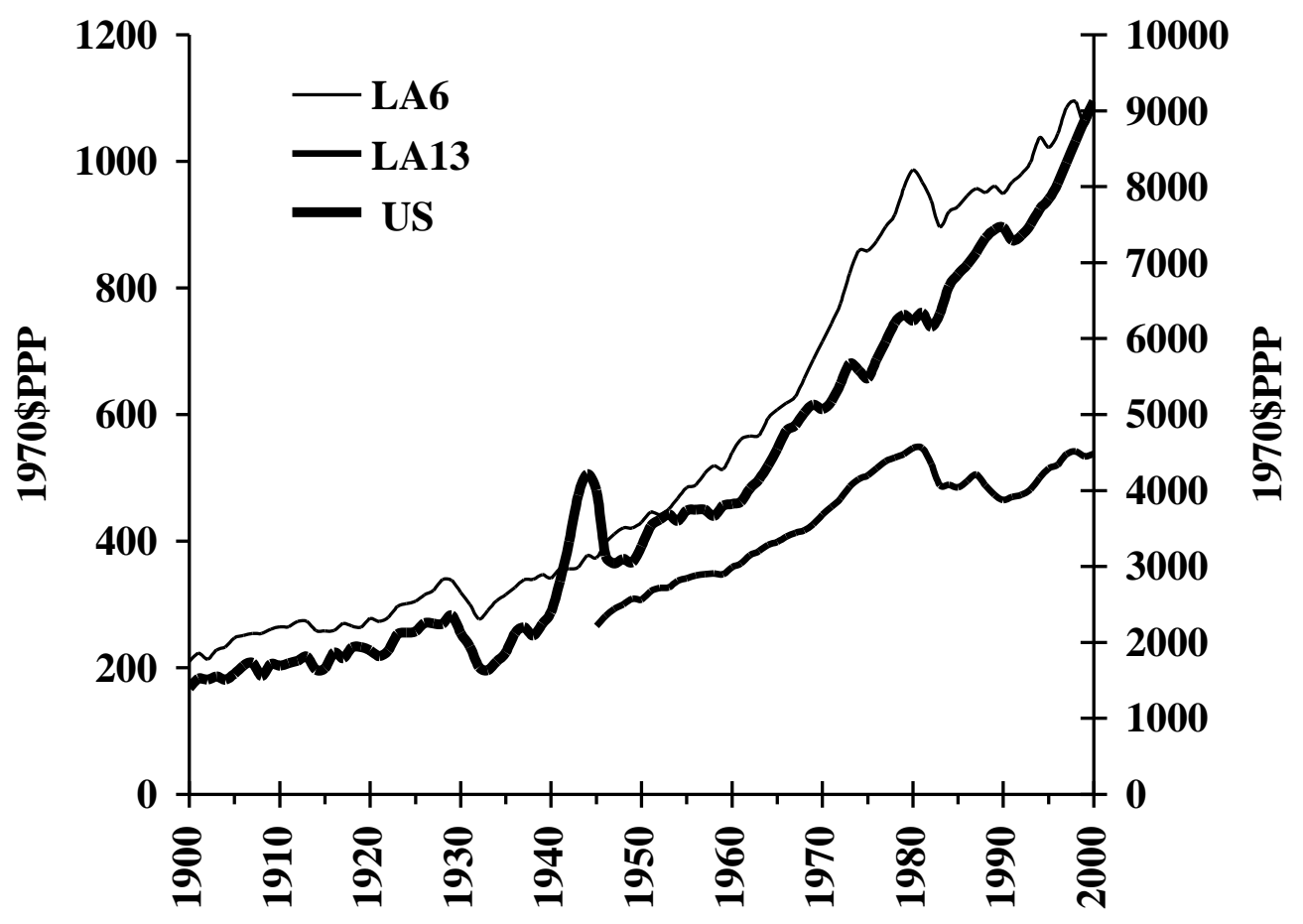

Note: LA6 and LA13 lie on the left-hand axis. US lies on the right-hand axis. Source: Table A1. 
Figure 7 Life expectancy at birth relative to the US

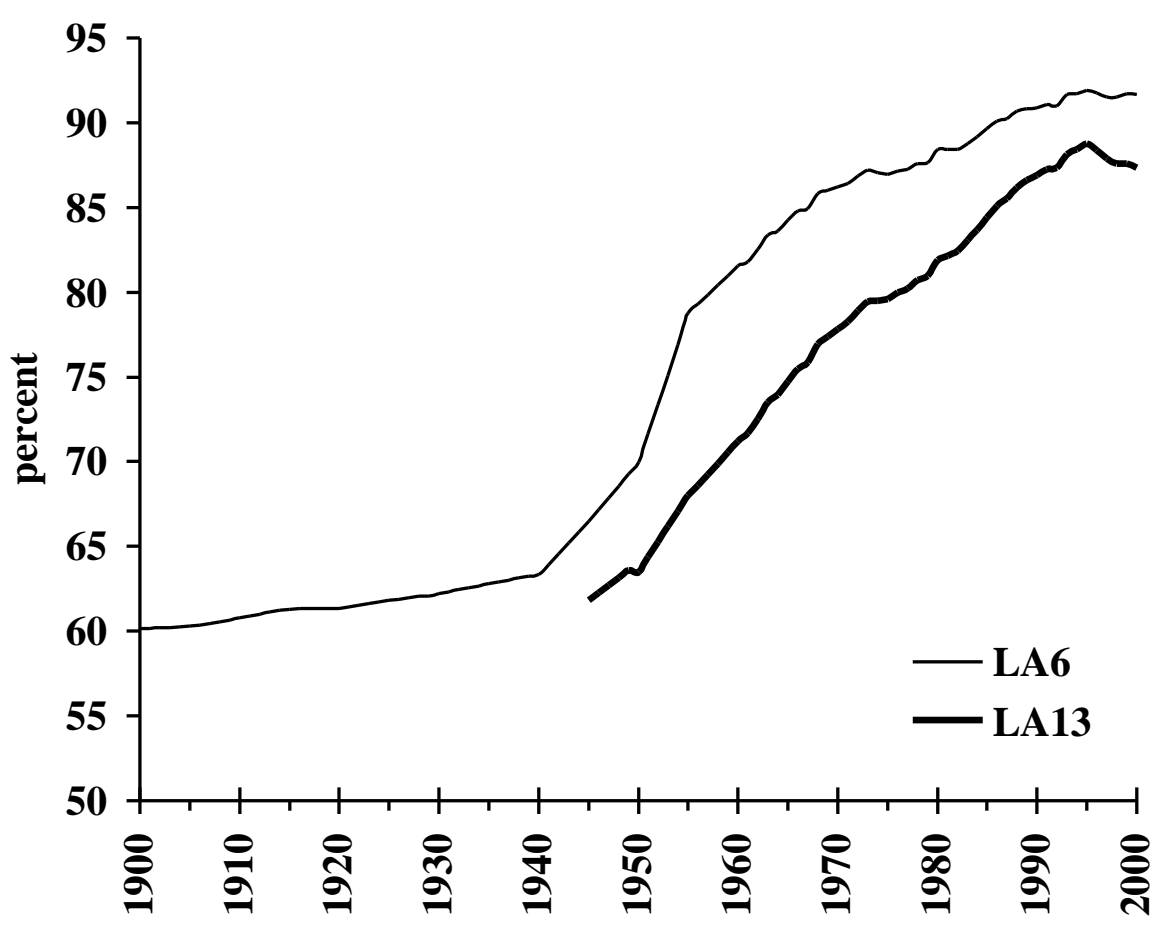

Source: Table A5.

Figure 8 Historical Living Standards Index relative to the US

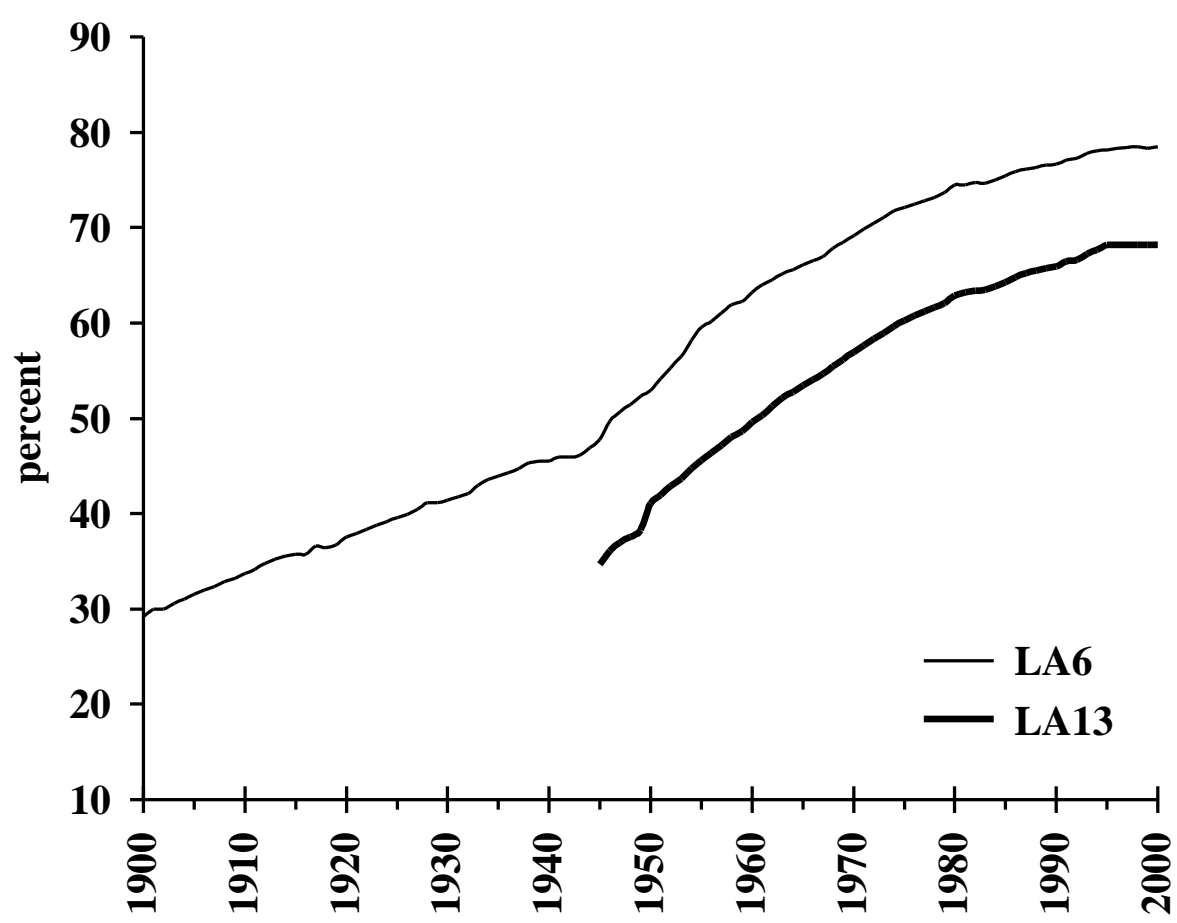

Source: Table A6. 
Figure 9 Latin American GDP per capita relative to Northern and Southern Europe, Asia and the US

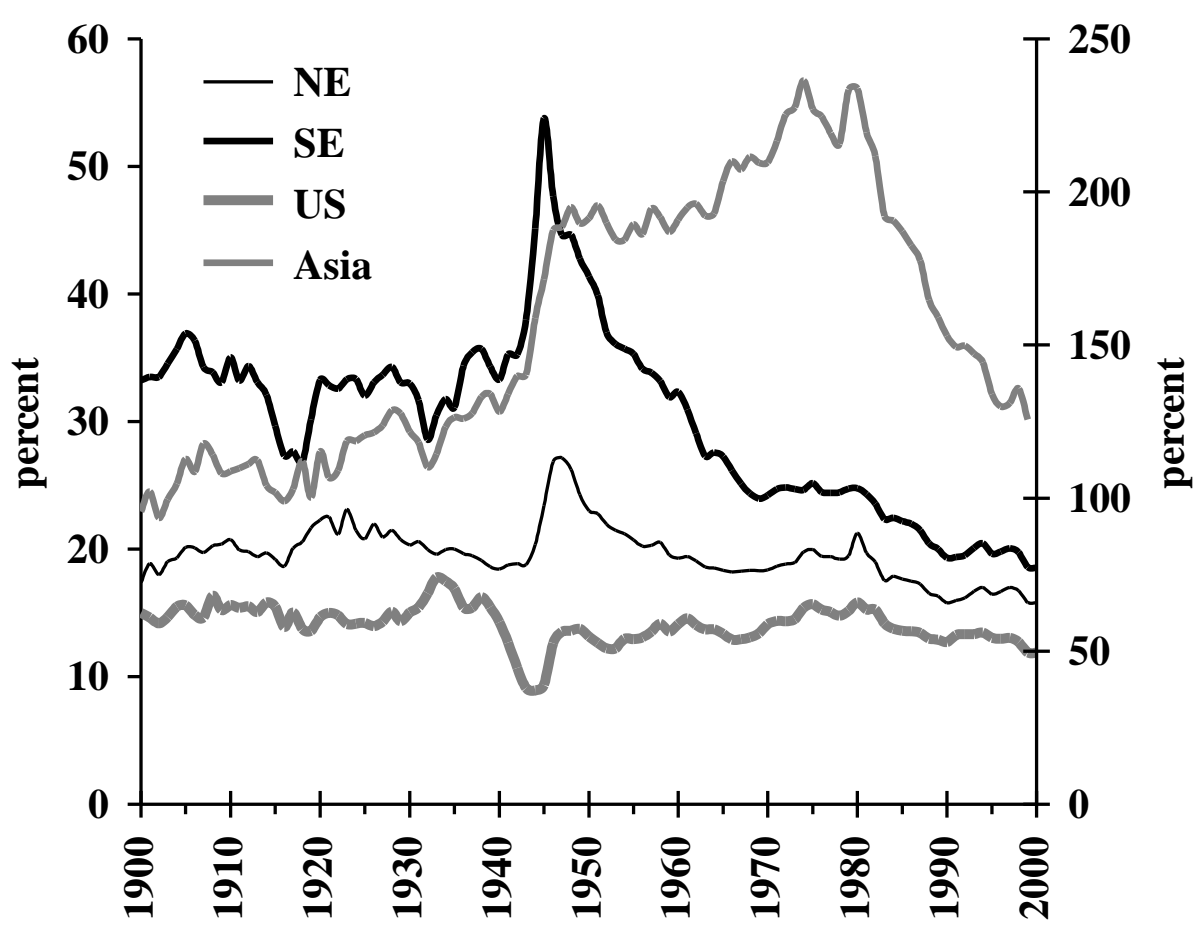

Note: Asia lies on the right hand axis, all others on left hand axis. Source: Table A1. 
Figure 10 Openness and growth in the LA6

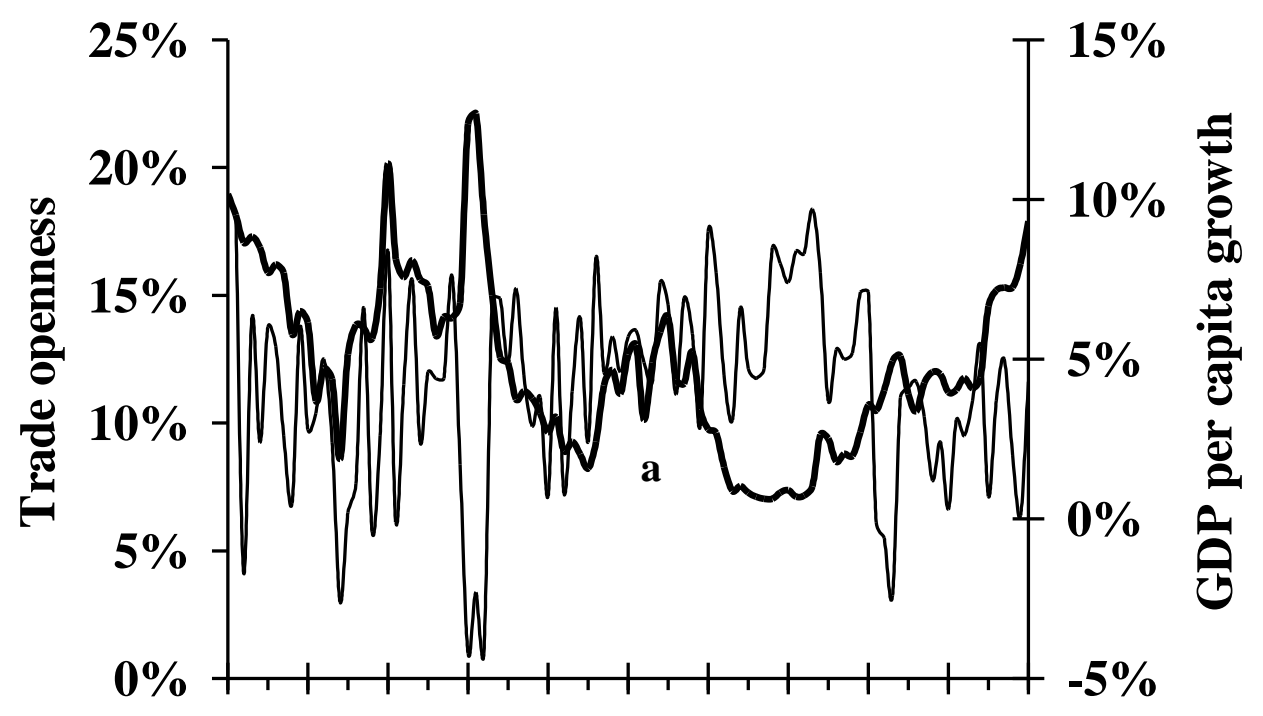

\section{- Trade openness - GDP}

Sources and notes: 'Trade openness' defined as the average of imports and exports divided by GDP (i.e. $(X+M) / 2 Y)$. Data on exports and imports from Astorga, Bergés and FitzGerald (2003); GDP per capita growth rates as for Table A1. 


\section{[Tables in Text]}

Table 1 Income per capita, literacy and life expectancy in Latin America

\begin{tabular}{lccccccccc}
\hline \hline & \multicolumn{3}{c}{$\begin{array}{c}\text { GDP per capita } \\
(1970 \text { PPP dollars })\end{array}$} & \multicolumn{3}{c}{$\begin{array}{c}\text { Literacy } \\
\text { (percent) }\end{array}$} & \multicolumn{4}{c}{$\begin{array}{c}\text { Life Expectancy } \\
\text { (years) }\end{array}$} \\
\hline & 1900 & 1950 & 2000 & 1900 & 1950 & 2000 & 1900 & 1950 & 2000 \\
\hline Argentina & 497 & 811 & 1,459 & 51 & 88 & 97 & 39 & 61 & 73 \\
Brazil & 114 & 245 & 874 & 35 & 49 & 85 & 29 & 43 & 68 \\
Chile & 284 & 592 & 1,602 & 44 & 79 & 96 & 29 & 49 & 75 \\
Colombia & 290 & 389 & 921 & 34 & 62 & 92 & 29 & 49 & 71 \\
Mexico & 240 & 519 & 1,284 & 24 & 61 & 91 & 25 & 48 & 73 \\
Venezuela & 94 & 719 & 1,014 & 28 & 51 & 93 & 28 & 51 & 73 \\
& & & & & & & & & \\
LA6 & 216 & 440 & 1,077 & 33 & 60 & 89 & 29 & 48 & 70 \\
LA13 & $\ldots$ & 319 & 538 & 25 & 46 & 82 & 31 & 43 & 67 \\
\hline \hline
\end{tabular}

Source: See Tables A1, A4 and A5.

Table 2 Growth and instability of GDP per capita in Latin America

\begin{tabular}{lccccccccc}
\hline \hline & \multicolumn{3}{c}{$1900-39$} & \multicolumn{3}{c}{ 1940-80 } & \multicolumn{3}{c}{ 1981-2000 } \\
\hline & Growth & S.Dev. & Volat. & Growth & S.Dev. & Volat. & Growth & S.Dev. & Volat. \\
Argentina & 1.0 & 5.0 & 4.3 & 1.7 & 4.7 & 2.8 & 0.6 & 5.2 & 16.5 \\
Brazil & 1.6 & 4.3 & 2.6 & 3.7 & 3.5 & 1.0 & 0.7 & 3.8 & 10.1 \\
Chile & 1.4 & 11.2 & 5.6 & 1.7 & 4.3 & 2.3 & 2.6 & 5.2 & 1.9 \\
Colombia & 0.3 & 3.0 & 7.9 & 2.1 & 2.2 & 1.0 & 0.7 & 4.2 & 5.8 \\
Mexico & 1.0 & 5.2 & 4.7 & 3.2 & 2.9 & 1.0 & 0.6 & 4.0 & 4.5 \\
Venezuela & 3.9 & 9.3 & 2.2 & 2.8 & 4.4 & 1.6 & -0.9 & 5.0 & 5.5 \\
LA6 & 1.3 & 3.5 & 2.2 & 2.7 & 2.0 & 0.7 & 0.6 & 2.4 & 4.4 \\
LA13 & - & - & - & $2.1^{\mathrm{a}}$ & $1.4^{\mathrm{a}}$ & $0.6^{\mathrm{a}}$ & -0.1 & 2.7 & 51.8 \\
\hline \hline
\end{tabular}

${ }^{a}$ 1945-80. Source: Table A1. 
Table 3 Mortality Rates in Latin America and US, 1960-2000

\begin{tabular}{lrrrrrrr}
\hline \hline & \multicolumn{1}{c}{ Latin America } & \multicolumn{2}{c}{ USA } \\
\hline & 1960 & 1970 & 1980 & 1990 & 2000 & 1960 & 2000 \\
& & & & & & & \\
Adult female (per 1,000 female adults) & 233 & 189 & 154 & 130 & 125 & 129 & 84 \\
Adult male (per 1,000 male adults) & 304 & 256 & 228 & 198 & 222 & 231 & 147 \\
Infant (per 1,000 live births) & 102 & 86 & 61 & 43 & 31 & 26 & 7 \\
Under-5 (per 1,000) & 154 & 123 & 82 & 53 & 36 & 30 & 9 \\
& & & & & & &
\end{tabular}

Source: World Bank (2004)

Table 4 Urbanisation and urban-rural literacy rates in LA6, 1900-2000

\begin{tabular}{ccc}
\hline & & \\
& Urbanisation ratio & Ratio of urban-rural literacy \\
$1900-10$ & 14 & 187 \\
$1911-20$ & 17 & \\
$1921-30$ & 24 & \\
$1931-40$ & & 185 \\
$1941-50$ & 45 & 198 \\
$1951-60$ & 46 & 141 \\
$1961-70$ & 63 & 159 \\
$1971-80$ & 70 & 134 \\
$1981-90$ & 76 & 128 \\
$1991-2000$ & 81 & 116 \\
\hline \hline
\end{tabular}

Source: Table A7. Note: these are simple averages in each decade for those countries for which there are data in Table A7, and are thus not entirely consistent. 
Table 5 The Standard of Living in Latin America in 2000 compared to the USA in 1900

\begin{tabular}{lcc}
\hline \hline & LA6 in 2000 & USA in 1900 \\
\hline GDP per capita (1970 PPP \$) & 1078 & 1478 \\
Life expectancy (years) & 70 & 48 \\
Literacy (percent) & 89 & 89 \\
HSLI & 0.68 & 0.57 \\
\hline \hline
\end{tabular}

Source: Tables A1, A4, A5 and A6.

Table 6 Per capita income, adult literacy and life expectancy relative to the US

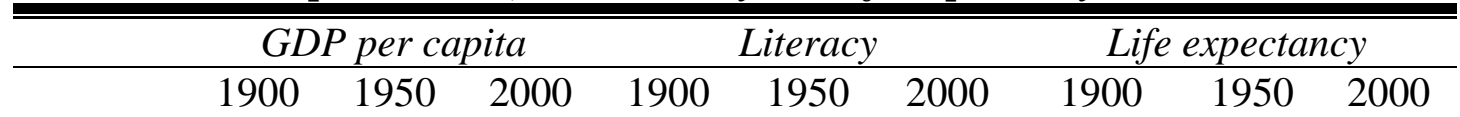

\begin{tabular}{lccccccccc} 
Argentina & 34 & 23 & 16 & 58 & 90 & 98 & 81 & 89 & 95 \\
Brazil & 8 & 7 & 10 & 39 & 51 & 86 & 61 & 63 & 88 \\
Chile & 19 & 17 & 18 & 49 & 81 & 97 & 60 & 71 & 98 \\
Colombia & 20 & 11 & 10 & 38 & 63 & 93 & 60 & 71 & 93 \\
Mexico & 16 & 15 & 14 & 27 & 62 & 92 & 52 & 70 & 94 \\
Venezuela & 6 & 21 & 11 & 31 & 52 & 94 & 58 & 75 & 95 \\
& & & & & & & & & \\
LA6 & 15 & 13 & 12 & 38 & 62 & 90 & 60 & 70 & 92 \\
LA13 & $\ldots$ & 9 & 6 & 29 & 47 & 83 & 64 & 64 & 87 \\
\hline \hline
\end{tabular}

Notes: as for Table 1. Sources: Tables A1, A4, A5. 